Supporting Information

\title{
Controlling Surface Phase Transition and Chemical Reactivity of O3-Layered Metal Oxide Cathodes for High-Performance Na-ion Batteries
}

Junhua Song, ${ }^{a, b \dagger}$ Kuan Wang, ${ }^{c \dagger}$ Jianming Zheng, ${ }^{a *}$ Mark H. Engelhard, ${ }^{a}$ Biwei Xiao, ${ }^{a}$ Enyuan Hu, ${ }^{d}$ Zihua Zhu, ${ }^{a}$ Chongmin Wang, ${ }^{a}$ Manling Sui ${ }^{c}$ Yuehe Lin, ${ }^{{ }^{*}}$ David Reed, ${ }^{a}$ Vincent L. Sprenkle, ${ }^{a}$ Pengfei Yan, ${ }^{c^{*}}$ Xiaolin $\mathrm{Li}^{a^{*}}$

a. Pacific Northwest National Laboratory, Richland, WA, 99352, USA

b. School of Mechanical and Materials Engineering, Washington State University, Pullman, WA 99164, USA

c. Beijing Key Laboratory of Microstructure and Properties of Solids, Institute of Microstructure and Properties of Advanced Materials, Beijing University of Technology, Beijing, 100124, China d. Chemistry Division, Brookhaven national laboratory, Upton, NY 11973, USA

Correspondence to be addressed to: J.M.Z. (xmzhjm@126.com), P.F.Y. (pfyan@bjut.edu.cn), Y.L. (yuehe.lin@wsu.edu) or X.L. (xiaolin.li@pnnl.gov)

$\uparrow$ These authors contributed equally to this work

₹ Currently at Research Institute (RI), NingDe Amperex Technology Limited, NingDe, Fujian, 352100, China

\section{Experimental Section}

Material synthesis: The O3-NaNMC682210 cathode was prepared by homogeneously mixing the $\mathrm{Ni}_{0.68} \mathrm{Mn}_{0.22} \mathrm{Co}_{0.10}(\mathrm{OH})_{2}$ precursor powder with $\mathrm{NaOH}$, preheating at $500^{\circ} \mathrm{C}$, and subsequent calcination at $650-750{ }^{\circ} \mathrm{C}$ for $20 \mathrm{hr}$ in pure $\mathrm{O}_{2}$. The heating and cooling rates were fixed at $5{ }^{\circ} \mathrm{C}$ $\mathrm{min}^{-1}$ and $2^{\circ} \mathrm{C} \mathrm{min}^{-1}$, respectively. An excess amount of $\mathrm{Na}(1 \mathrm{~mol} \%)$ was used to compensate the loss of $\mathrm{Na}$ during calcination. $\mathrm{NaNi}_{0.45} \mathrm{Mn}_{0.5} \mathrm{Ti}_{0.05} \mathrm{O}_{2}$ was synthesized by a classical solid-state reaction. Stoichiometric values of $\mathrm{Na}_{2} \mathrm{CO}_{3}$ (Alfa-Aesar), $\mathrm{NiO}$ (Alfa-Aesar), $\mathrm{Mn}_{2} \mathrm{O}_{3}$ (Alfa-Aesar) and $\mathrm{TiO}_{2}$ (Alfa-Aesar) were ball milled and calcined at $1000^{\circ} \mathrm{C}$ for $12 \mathrm{hr}$ in $\mathrm{O}_{2}$ atmosphere. $\mathrm{NaNiO}_{2}$ was synthesized by mixing $\mathrm{Na}_{2} \mathrm{O}$ (Alfa-Aesar) and $\mathrm{NiO}$ (Alfa-Aesar) in a stoichiometric ratio and subsequent calcination at $650^{\circ} \mathrm{C}$ under $\mathrm{O}_{2}$ for $12 \mathrm{hr}$.

Electrochemical measurements: Battery performance was tested on an Arbin BT-2000 battery tester at room temperature. R2032 coin cells were assembled with PE separators (Celgard2500) in an argon-filled glove box (MBraun) for both half-cell and full-cell evaluation. The electrodes of O3-NaNMC682210 and hard carbon (Kureha Battery Materials Japan Co. Ltd.) were prepared by casting a slurry of active material/PVDF/Super-P (85:7.5:7.5) from NMP on aluminum current collector and vacuum drying at $70^{\circ} \mathrm{C}$ overnight. Typical loading of the electrodes was $\sim 4$ $\mathrm{mg} \mathrm{cm}^{-2}$. Carbonate conventional electrolyte was $1 \mathrm{M} \mathrm{NaPF}_{6}$ (Oakwood Product, Inc) in ethylene carbonate (battery grade, BASF)/ dimethyl carbonate (battery grade, BASF) (1:1 by volume) with the addition of $2 \mathrm{wt} . \%$ fluoroethylene carbonate. Localized high concentration advanced electrolyte was prepared by mixing 6M NaFSI (Solvionic) in dimethoxyethane (battery grade, BASF), which was then diluted to $1.2 \mathrm{M}$ with bis(2,2,2-trifluoroethyl) ether (Synquest Laboratories). The electrolyte salts were dried at $100^{\circ} \mathrm{C}$ under vacuum for $24 \mathrm{hr}$ and the solvents 
were dried with molecular sieves ( $4 \AA$ ) until water content $<20$ ppm using the Karl-Fischer method before use. The conductivity of carbonate and advanced electrolyte is $4.54 \mathrm{mS} \mathrm{cm}^{-1}$ and $3.03 \mathrm{mS} \mathrm{cm}{ }^{-1}$, respectively. ${ }^{1}$ Half-cells were tested against sodium metal with $\sim 70 \mu$ electrolyte. Full-cells were assembled with pristine cathode and pre-cycled hard carbon anode (See Supplementary Note 1$)$. The $\mathrm{n} / \mathrm{p}$ ratio was $1.1: 1$ and the electrolyte amount were controlled to 40 $\mu l$. Full cell anode was prepared with the same composition as in half-cell, except the areal active material loading was increased to $\sim 13 \mathrm{mg} / \mathrm{cm}^{2}$. The cathode loading for high areal capacity fullcells were $\sim 14 \mathrm{mg} \mathrm{cm}^{-2}(1.2-4.1 \mathrm{~V})$ and $\sim 17 \mathrm{mg} \mathrm{cm}^{-2}(1.2-3.9 \mathrm{~V})$. Hard carbon half-cells with conventional or advanced electrolyte were tested between $0.02-1 \mathrm{~V}$ at a current density of $50 \mathrm{~mA}$ $\mathrm{g}^{-1}$. Pouch cell was fabricated with a capacity of $60 \mathrm{mAh}$ and operated between 1.2-3.9V.

Materials characterization: Powder X-ray diffraction (XRD) of the synthesized samples was performed on a Rikagu MiniFlex 600 with $\mathrm{Cu} \mathrm{K \alpha}$ radiation operated at $40 \mathrm{kV}$ and $15 \mathrm{~mA}$. The cells for ex-situ XRD measurements were dissembled in the glove box as soon as they reached target cut-off potentials. The cathodes were gently rinsed by DMC or DME for those cycled in conventional or advanced electrolyte, respectively. The cathodes were sealed with Kapton tape after overnight drying in the glove box and taken out for XRD measurement immediately. The lattice parameters were refined by the Rietveld method with the General Structure Analysis Software (see Supplementary Note 3). X-ray photoelectron spectroscopy (XPS) measurements were performed with a Physical Electronics Quantera Scanning X-ray Microprobe. Focused ion beam (FIB)/scanning electron microscopy (SEM) imaging and TEM specimen preparation were conducted on a FEI Helios DualBeam FIB operated at 2-30 kV. Thin-section TEM specimens were prepared from electrode foil by a standard lift-out procedure. The FIB-prepared cathode samples were imaged by a FEI Titan60-300 S/TEM microscope operated at $300 \mathrm{kV}$. The microscope was equipped with a probe spherical aberration corrector, which enabled sub-angstrom imaging using STEM-HAADF detectors. For STEM-HAADF imaging, the inner and outer collection angles of the annular dark-field detector were set at 58.5 and $200 \mathrm{mrad}$, respectively. The STEM-EELS data were collected in dual-EELS mode to obtain both zero-loss and core-loss spectra. Core-loss EELS were calibrated by the corresponding zero-loss EELS before further analysis using Digital Micrograph (Version 2.11 (Gatan Inc.)). ICP analysis was conducted on an Optima 7300DV, PerkinElmer. The tap density of NaNMC682210 was measured by mechanically tapping a graduated cylinder containing the cathode particles until no further volume change is observed. The measured tap density is $2 \mathrm{~g} \mathrm{~cm}^{-3}$.

\section{Supplementary Note 1}

\section{Synthesis of the $\mathrm{Ni}_{0.68} \mathrm{Mn}_{0.22} \mathrm{Co0} .10(\mathrm{OH})_{2}$ precursors}

Briefly, an aqueous solution $\left(2.0 \mathrm{~mol} \mathrm{~L}^{-1}\right.$ ) consisting of $\mathrm{NiSO}_{4}$ (Alfa Aesar), $\mathrm{CoSO}_{4}$ (Alfa Aesar), and $\mathrm{MnSO}_{4}$ (Alfa Aesar) with an appropriate molar ratio was continuously fed into the stirring tank. A NH $4{ }_{4} \mathrm{OH}$ (Alfa Aesar) solution $\left(10 \mathrm{~mol} \mathrm{~L}^{-1}\right.$ ) as the chelating agent and a $\mathrm{NaOH}$ (Alfa Aesar) solution $\left(4.0 \mathrm{~mol} \mathrm{~L}^{-1}\right)$ were added separately at the same time. The temperature, stirring speed and $\mathrm{pH}$ value were carefully controlled at $50^{\circ} \mathrm{C}, 1000 \mathrm{rpm}$ and $\mathrm{pH}=11$ during the entire precipitation reaction. After the reaction was finished, the precursor was filtered, thoroughly washed with distilled water, and dried overnight at $110^{\circ} \mathrm{C}$.

\section{Characterization of pristine O3-NaNMC682210 cathodes}

The scanning electron microscopy (SEM) image of the O3-NaNMC682210 shows spherical particles with similar size but rougher surface morphology compared to the metal hydroxide 
precursors (Figure S1a and S2). Inductively coupled plasma mass spectrometry (ICP) confirms the designed chemical composition. The molar ratio of Ni:Mn:Co is 68:22:10 (Figure S1a inset). Rietveld refinement of the X-ray diffraction pattern (XRD) reveals that the cathode material has the desired O3-structure of rhombohedral $\mathrm{R} \overline{3} \mathrm{~m}$ space group (Supplementary Note 3 and Figure $\mathrm{S} 1 b){ }^{2}$ Trace amount of $\mathrm{NiO}$ was observed in the XRD while the amount was minimized by careful control of the annealing conditions (Figure S3). Figure S1c is a representative scanning transmission electron microscopy-high-angle annular dark-field (STEM-HAADF) image of an O3-NaNMC682210 primary particle. The interlayer spacing is $\sim 5.2 \AA$, consistent with the value of a typical O3-type SIB cathode. ${ }^{3}$ The structure was also examined by the scanning transmission electron microscopy (STEM) and elemental dispersive spectroscopy (EDS) mappings, which show evenly distributed transition metals (Figure S1d-g). The spherical secondary particles were consisted of densely packed primary particles (Figure S4) of good crystallinity. The primary particle surface has only one or two atomic layers of reconstruction and negligible rock salt phase was observed (Figure S4d).

\section{Pre-cycle of hard carbon anodes}

For O3-NMC682210-hard carbon full-cells, hard carbon anodes were pre-cycled in half-cells between $0.02-1 \mathrm{~V}$ vs. $\mathrm{Na} / \mathrm{Na}^{+}$for 3 cycles and then reassembled into full-cells. The hard carbon anodes were pre-cycled in the corresponding electrolyte. The pre-cycled hard carbon anodes were dissembled at the charged (de-sodiated) state for full-cell assembly. The pre-cycling of hard carbon can improve the initial Coulombic efficiency by pre-forming an intact SEI layer. ${ }^{4}$

\section{Supplementary Note 2}

\section{Electrochemical Impedance Spectroscopy}

The three-electrode EIS tests were carried out on a Biologic VMP3 Multichannel Potentiostat with a frequency range of $0.01-1 \mathrm{MHz}$ and an amplitude of superimposed $\mathrm{AC}$ signal of $5 \mathrm{mV}$. The three-electrode cell was fabricated in the form of coin cells except that a polymer coated copper wire with polished ends was placed between two pieces of separators. The end of the copper wire was slurry coated with lithium titanate as reference electrode in the three-electrode EIS measurement while $\mathrm{Na}$ metal as the counter electrode.

\section{Supplementary Note 3 XRD Refinement}

The lattice parameters were refined by the Rietveld method with the General Structure Analysis Software (GSAS program, Los Alamos National Laboratory). The refinements were carried out with the $\alpha-\mathrm{NaFeO}_{2}$-type hexagonal structure ( $\left.\mathrm{R} \overline{3} \mathrm{~m}\right)$ in which the $\mathrm{Na}^{+}$ions occupy the $3 \mathrm{a}(0,0,1 / 2)$ sites, Fe is located in the $3 \mathrm{~b}(0,0,0)$ sites, and $\mathrm{O}$ is located in the $6 \mathrm{c}\left(0,0, \mathrm{Z}_{\text {oxy }}\right)$ sites (zoxy is close to $1 / 4)$. 


\section{Supporting Figures}
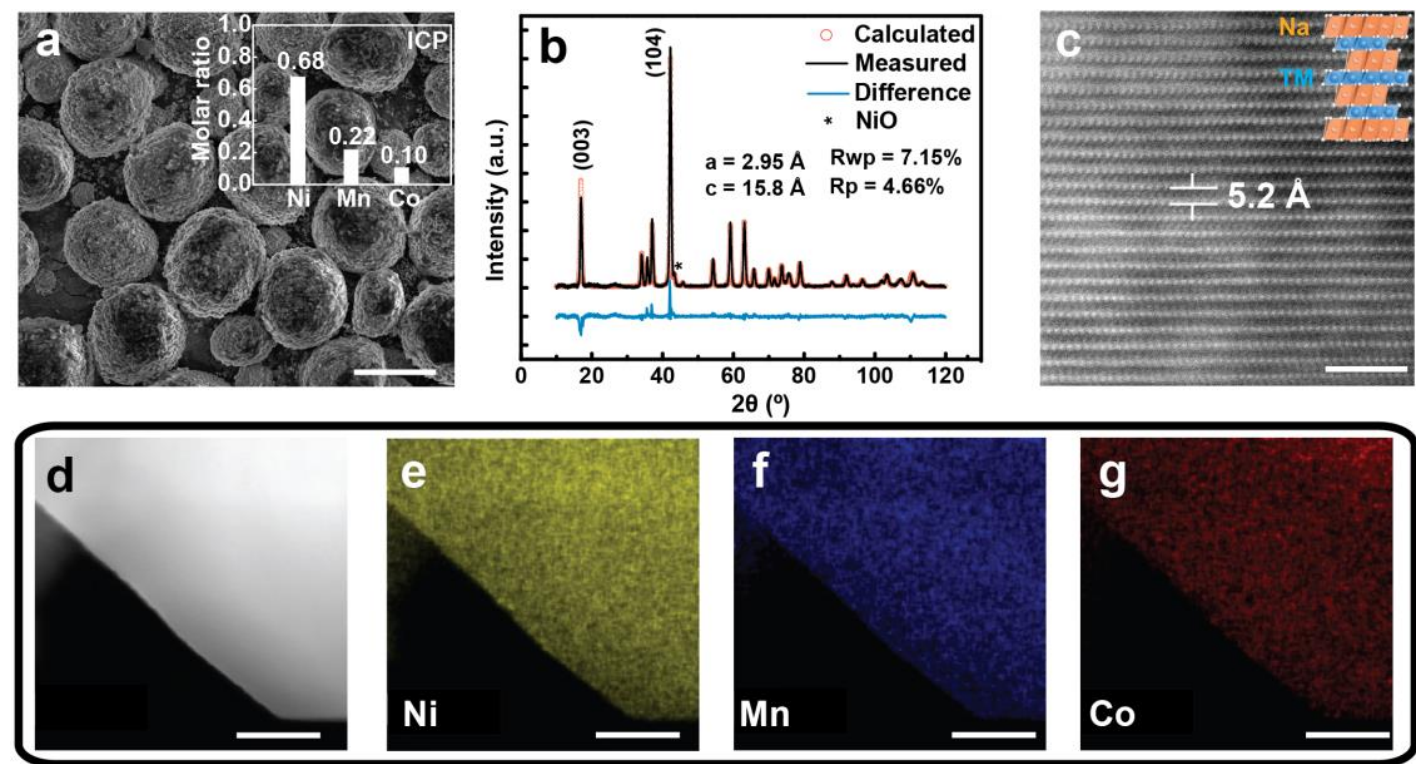

Figure S1. Characterization of the pristine O3-NaNMC682210 cathode material. a, A representative SEM image of the cathode microspheres; inset: ICP result of the transition metal molar ratio $( \pm 0.02)$. Scale bar: $10 \mu \mathrm{m}$. b, XRD characterization and Rietveld refinement. $\mathbf{c}, \mathrm{A}$ typical STEM-HAADF image of O3-NaNMC682210. Inset: schematic layer structure of the cathode. Scale bar: $4 \mathrm{~nm}$. d, STEM image of a primary particle. e-g, EDS mappings of Ni, Mn and Co of the particle in $\mathbf{d}$. Scale bars: $30 \mathrm{~nm}$.

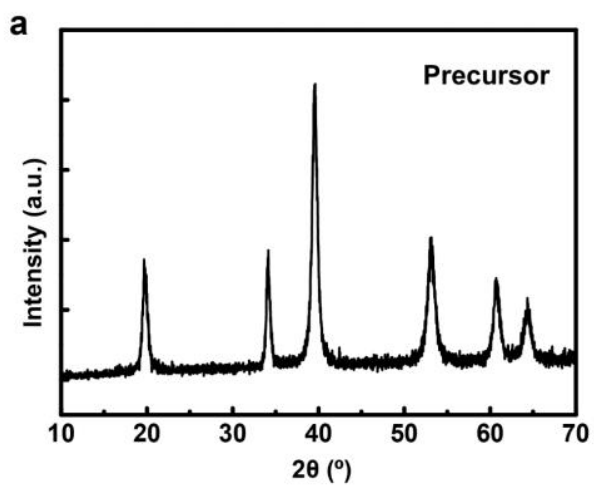

b

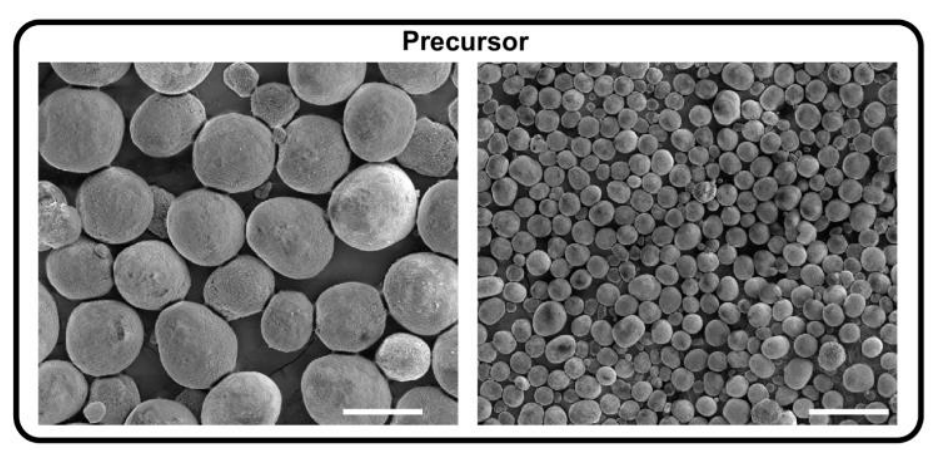

Figure S2. Characterization of the $\mathrm{Ni}_{0.68} \mathrm{Mn}_{0.22} \mathrm{Co} \mathbf{0}_{.10}(\mathrm{OH})_{2}$ precursor. a, A typical XRD pattern of the precursor. b, SEM images of the precursor microspheres. Scale bar: $10 \mu \mathrm{m}$ (left) and $40 \mu \mathrm{m}$ (right). 


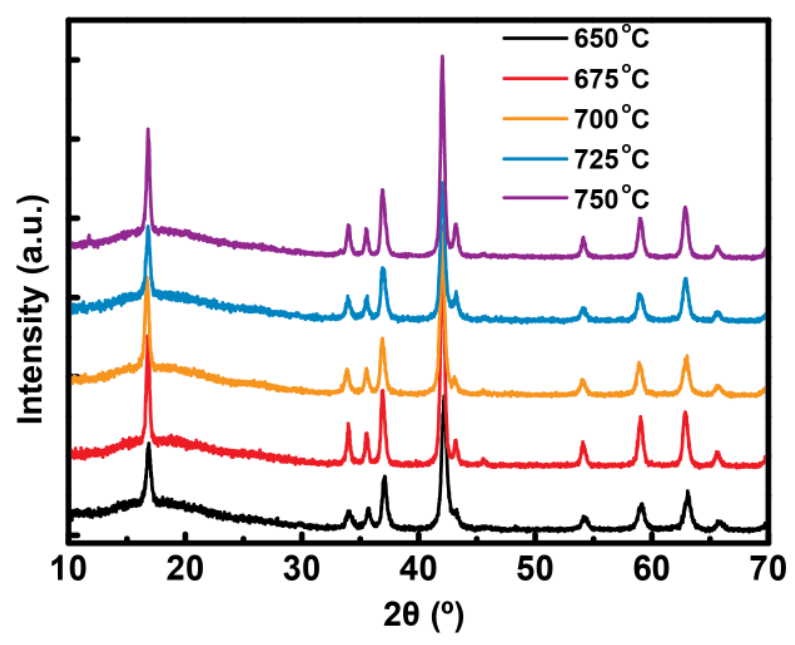

Figure S3. XRD patterns of the O3-NaNMC682210 material obtained at different annealing temperatures.

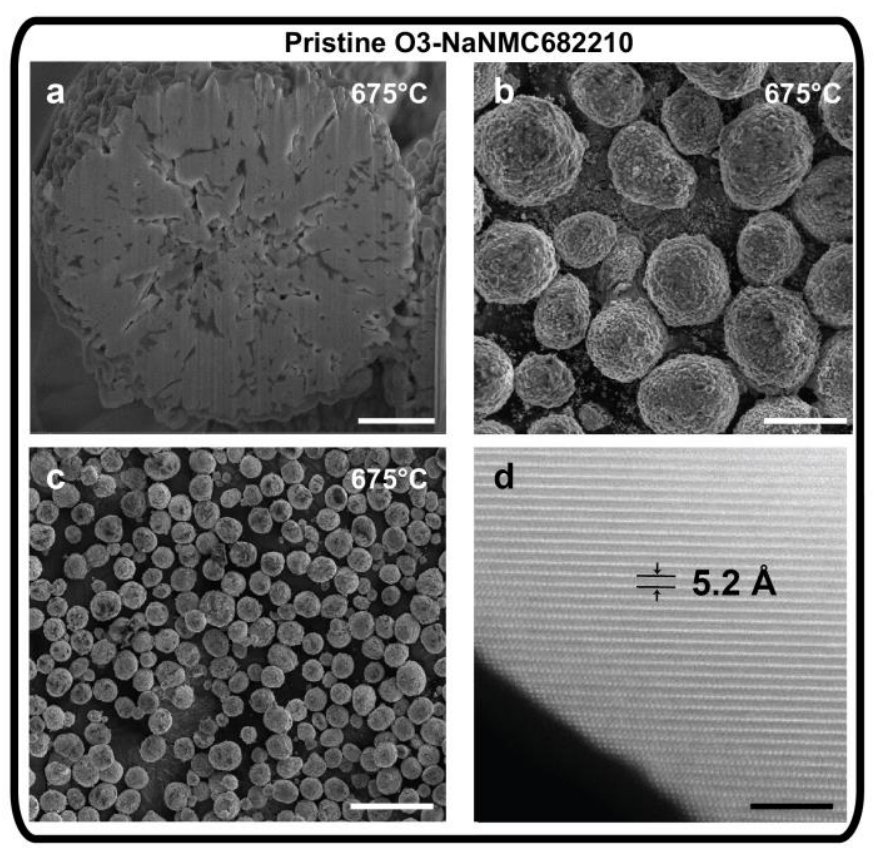

Figure S4. More morphological and structural characterizations of the pristine O3NaNMC682210 material. a, A typical cross section SEM image of an O3-NaNMC682210 microsphere. b-c, SEM images showing the uniformity of secondary microspheres of O3NaNMC682210. d, A typical STEM-HAADF image of a primary particle showing the edge and the bulk structure. Scale bars: $5 \mu \mathrm{m}(\mathbf{a}), 10 \mu \mathrm{m}(\mathbf{b}), 40 \mu \mathrm{m}$ (c) and $4 \mathrm{~nm}(\mathbf{d})$. 

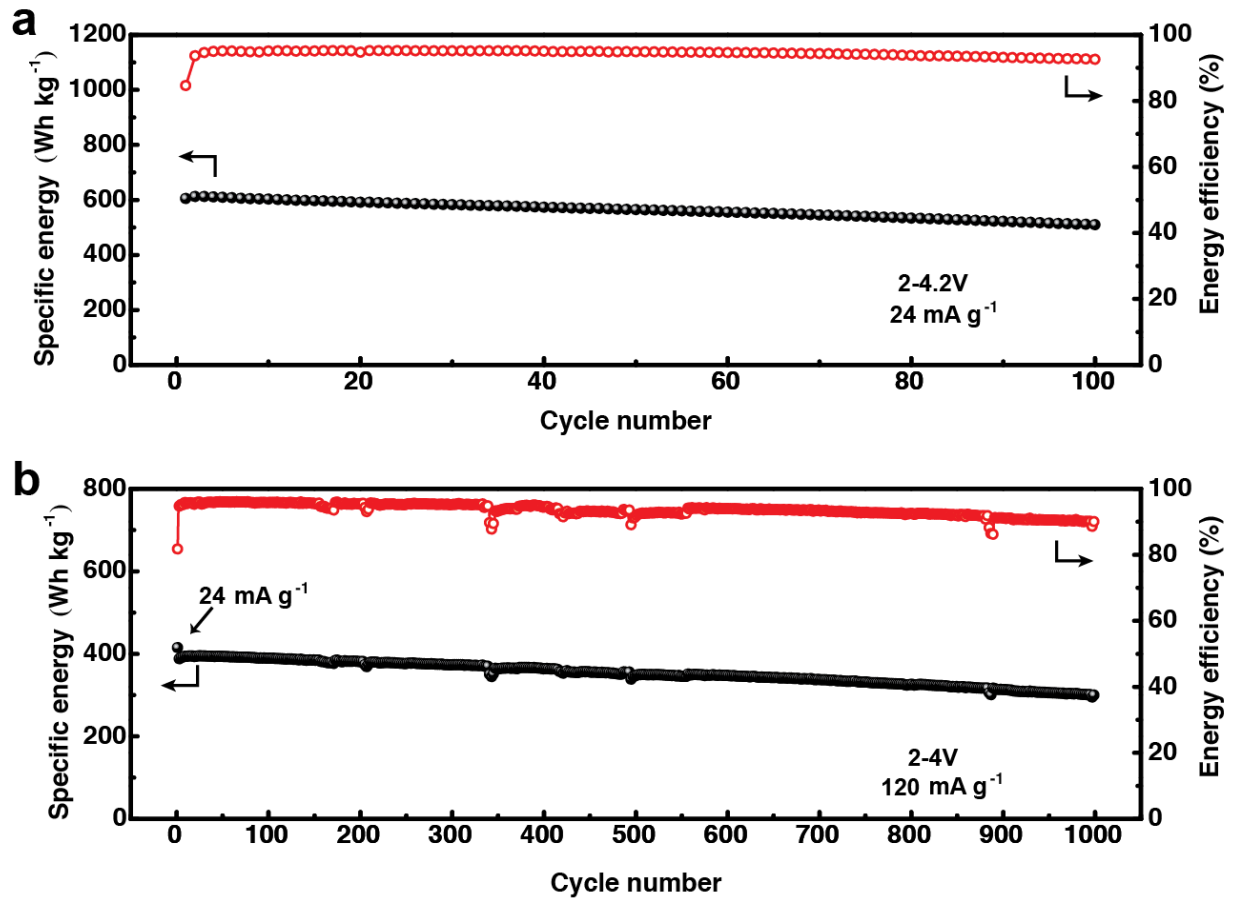

Figure S5. Specific energy and energy efficiency of the O3-NaNMC682210 half-cells with advanced electrolyte. a, The cell in Figure 1b. b, The cell in Figure 1e. 
a

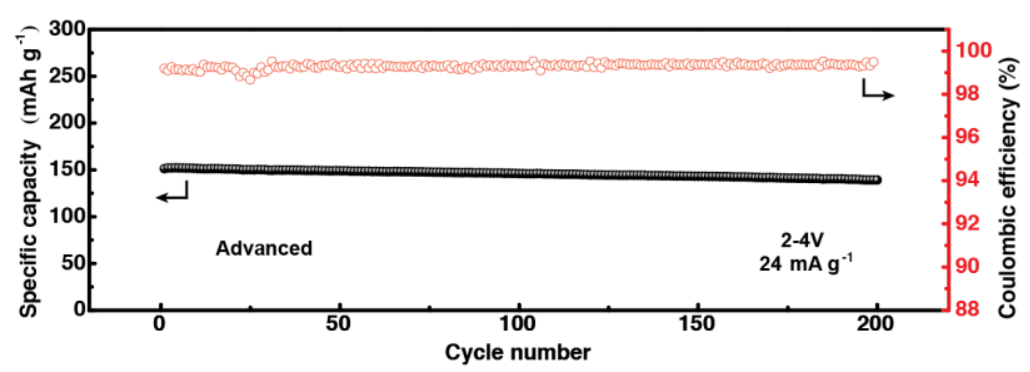

b

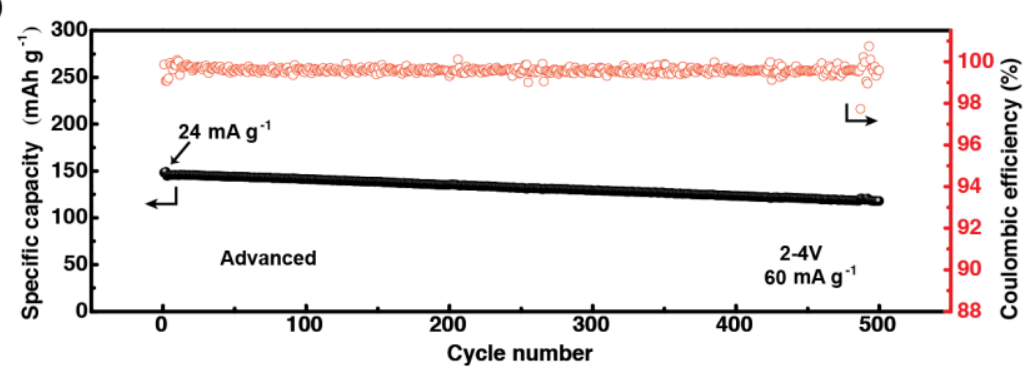

C

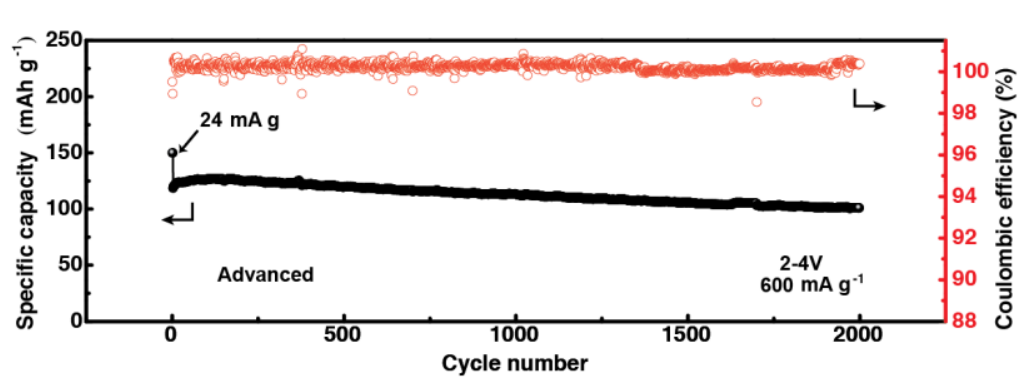

Figure S6. Electrochemical performance of the O3-NaNMC682210 half-cells cycled at different current densities between 2-4V. a, $24 \mathrm{~mA} \mathrm{~g}^{-1}$. b, $60 \mathrm{~mA} \mathrm{~g}^{-1}$. c, $600 \mathrm{~mA} \mathrm{~g}^{-1}$. The capacity retention is $92 \%$ over 200 cycles at $24 \mathrm{~mA} \mathrm{~g}^{-1}, 85 \%$ over 500 cycles at $60 \mathrm{~mA} \mathrm{~g}^{-1}$, and $85 \%$ over 2000 cycles at $600 \mathrm{~mA} \mathrm{~g}^{-1}$. 

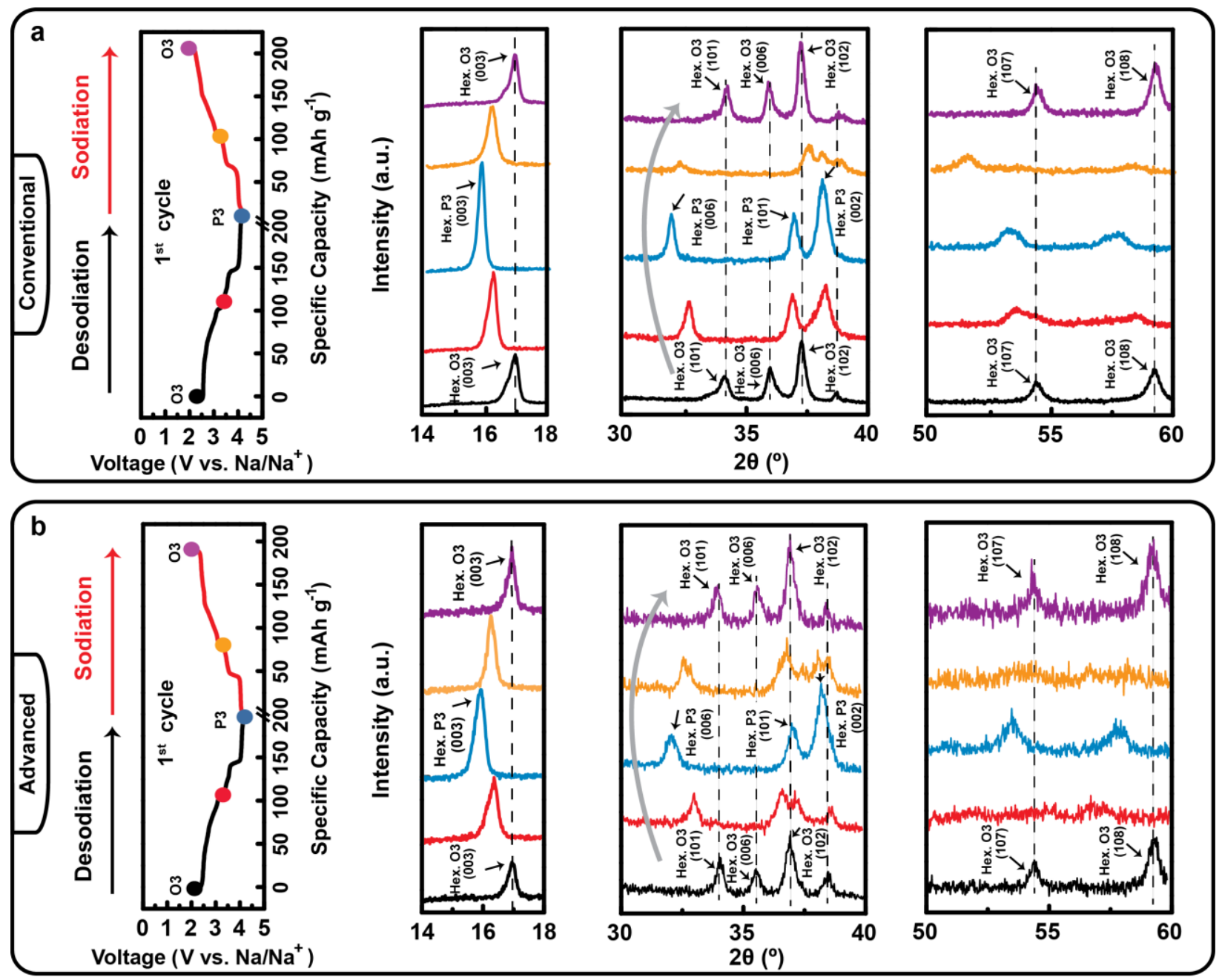

Figure S7. Charge/discharge curve and $1^{\text {st }}$ cycle $e x$-situ XRD of O3-NaNMC682210 between 2-4.2V| a, In conventional electrolyte. b, In advanced electrolyte.

The phase transition of O3-NaNMC682210 upon desodiation/sodiation is similar to the literature reports of typical Ni-rich O3-NaTMOs. ${ }^{5}$ The XRD patterns were collected during the initial cycle at different desodiation/sodiation stages $(2.1 \mathrm{~V}$ charge, $3.1 \mathrm{~V}$ charge, $4.2 \mathrm{~V}$ charge, $3.1 \mathrm{~V}$ discharge and $2 \mathrm{~V}$ discharge) in conventional and advanced electrolyte. Side-by-side comparison shows that the phase transitions are highly reversible in the $1^{\text {st }}$ cycle in both electrolytes. The (003) peak at full charge state $(4.2 \mathrm{~V})$ shifts left and can be almost fully reversed to its $\mathrm{O} 3$ position at full discharge state $\left(2 \mathrm{~V}\right.$ vs. $\left.\mathrm{Na} / \mathrm{Na}^{+}\right)$. 

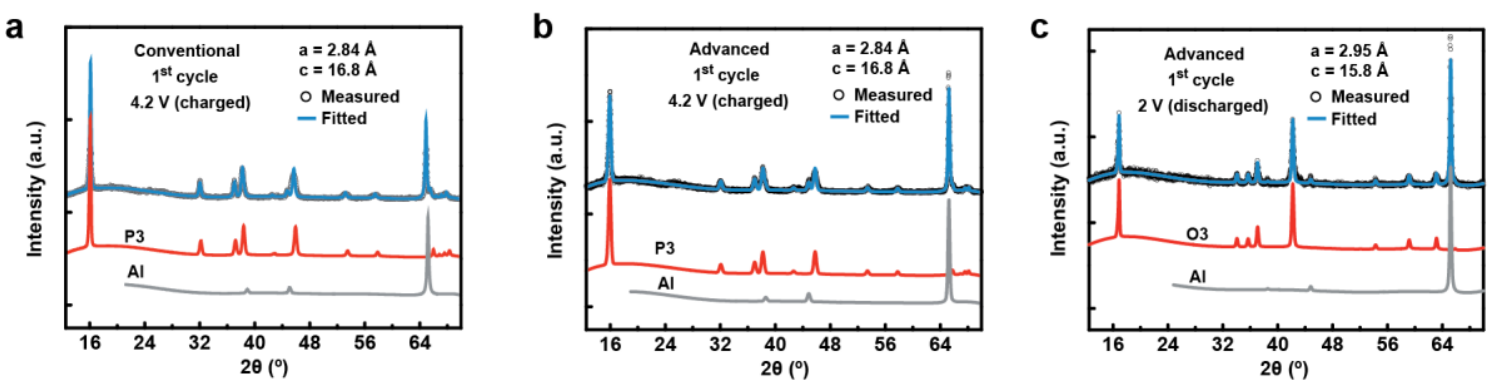

Figure S8. XRD refinement of O3-NaNMC682210 during the $1^{\text {st }}$ cycle. $a-b$, Charge-state $(4.2 \mathrm{~V})$ in conventional electrolyte (a) and in advanced electrolyte (b). c, Discharge-state (2V) in advanced electrolyte.

The $1^{\text {st }}$ cycle ex-situ XRD at fully charged state (4.2V) shows monoclinic P3 phase without any impurity phase in both advanced and conventional electrolytes $(\mathbf{a}, \mathbf{b})$. The lattice parameters of $\mathrm{P} 3$ phase are $\mathrm{a}=2.84 \AA$ and $\mathrm{c}=16.8 \AA$. The $\mathrm{P} 3$ phase can be fully reversed back to $\mathrm{O} 3$ phase after discharge to $2 \mathrm{~V}(\mathbf{c})$ with lattice parameters of $\mathrm{a}=2.95 \AA, \mathrm{c}=15.8 \AA$.

a

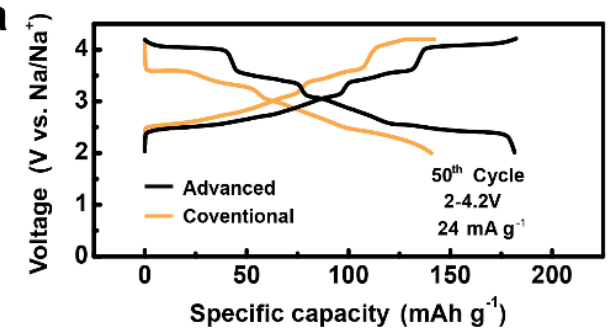

C

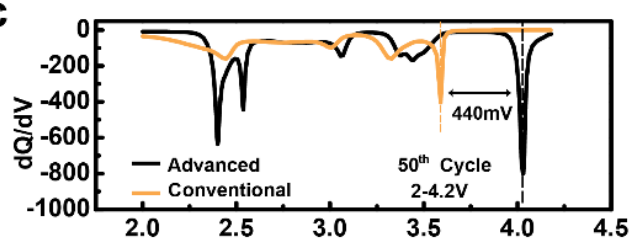

b

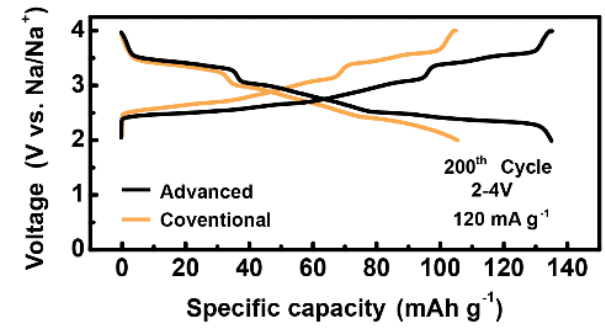

d

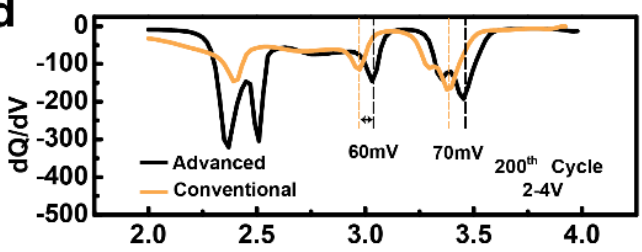

Figure S9. Charge/discharge curves and $d Q / d V$ analyses of O3-NaNMC682210 cycled in advanced and conventional electrolytes. a, The $50^{\text {th }}$ cycle charge/discharge curves of the cells in Figure 1b. b, The $200^{\text {th }}$ cycle charge/discharge curves of the cells in Figure 1e. c-d, Comparison of $\mathrm{dQ} / \mathrm{dV}$ plots derived from $\mathbf{a}$ and $\mathbf{b}$ at $50^{\text {th }}(\mathbf{c})$ and $200^{\text {th }}$ cycle $(\mathbf{d})$. 


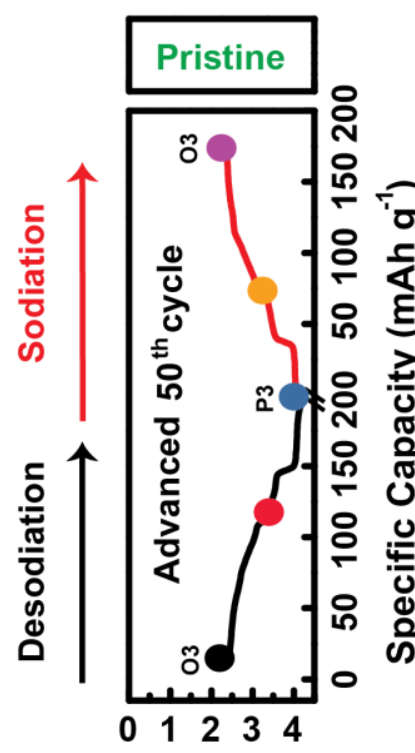

Voltage (V vs. $\mathrm{Na} / \mathrm{Na}^{+}$)
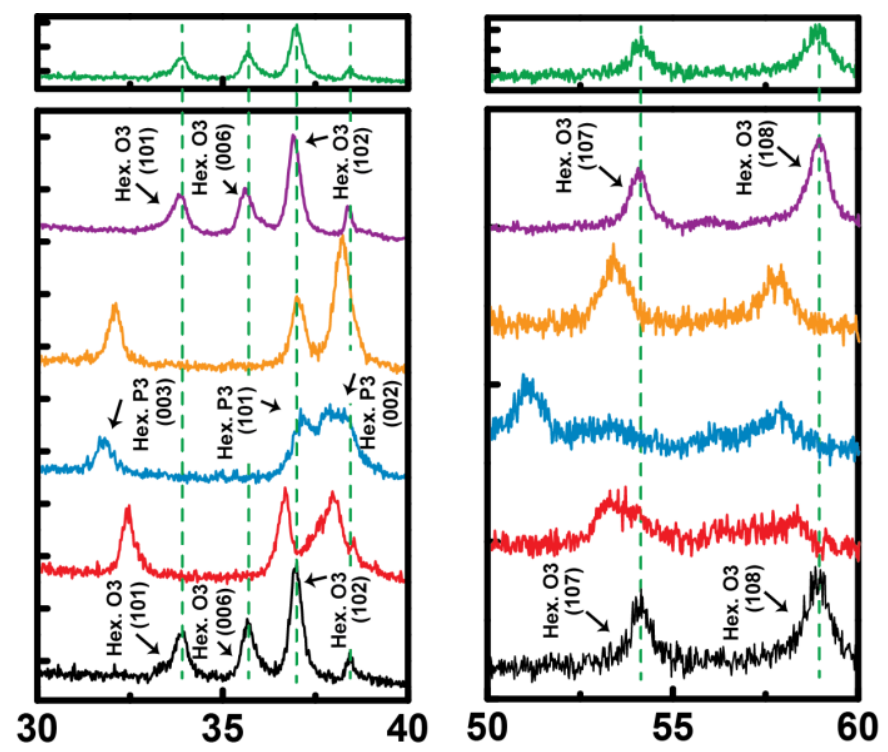

$2 \theta\left({ }^{\circ}\right)$

Figure S10. Charge/discharge curve and ex-situ XRD showing the phase evolution of the O3NaNMC682210 at the $50^{\text {th }}$ cycle between $2-4.2 \mathrm{~V}$ in advanced electrolyte.

The (003) peak positions at full discharge states are similar to the pristine cathode $\left(16.94^{\circ}\right)$. This indicates the good reversibility of the $\mathrm{O} 3$ phase cycled in the advanced electrolyte. 

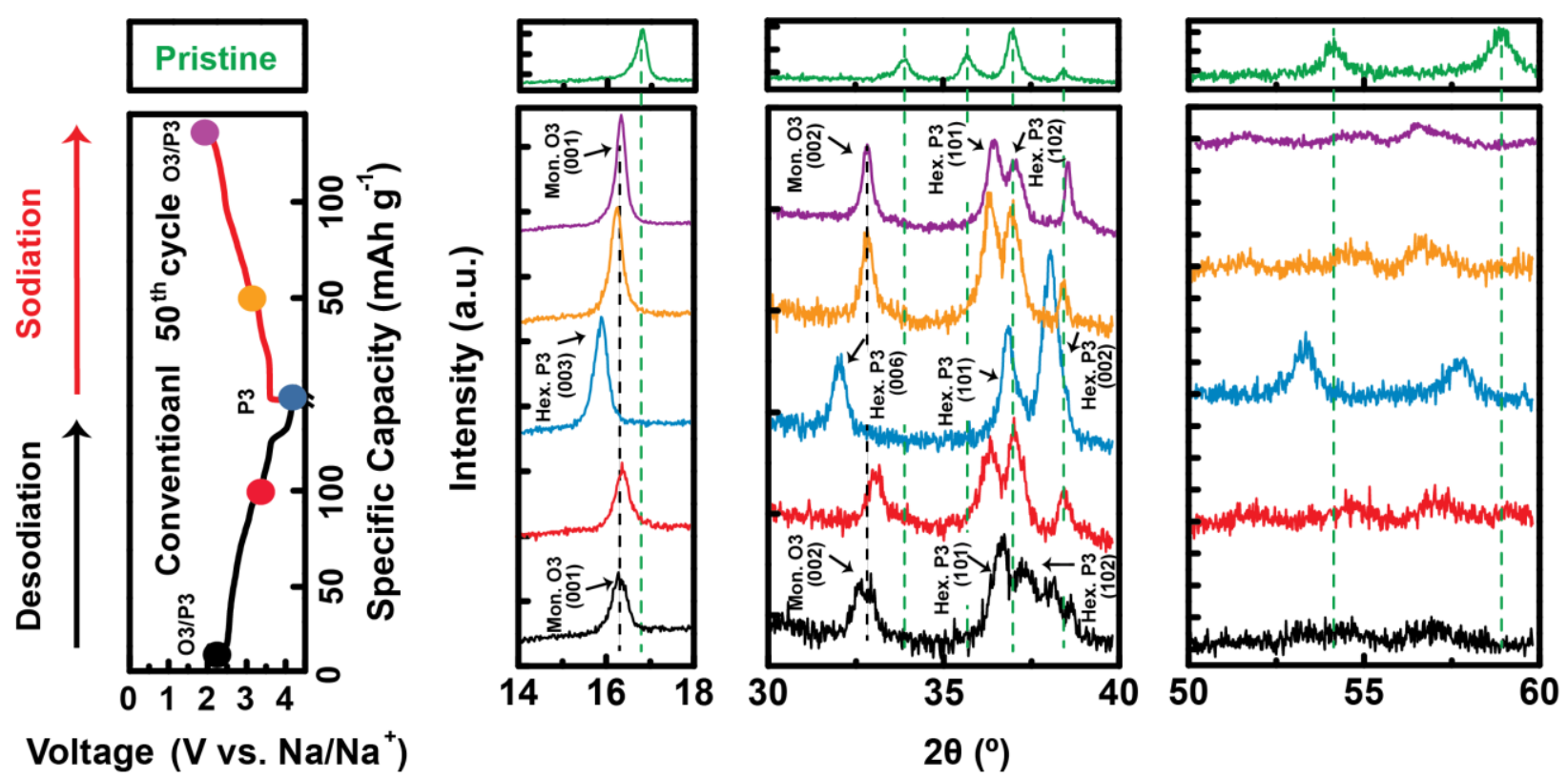

Figure S11. Charge/discharge curve and $e x$-situ XRD showing the phase evolution of the O3NaNMC682210 at the $50^{\text {th }}$ cycle between $2-4.2 \mathrm{~V}$ in conventional electrolyte.

The (003) peak positions at full discharge states shifted to $16.39^{\circ}$, compared to the $16.94^{\circ}$ of the pristine cathode. This indicates the poor reversibility of the $\mathrm{O} 3$ phase in the conventional electrolyte.

The $1^{\text {st }}$ cycle ex-situ XRD (Figure S7) shows almost fully reversible phase transition of the cathode structure from $\mathrm{O} 3$ to $\mathrm{P} 3$ and back to $\mathrm{O} 3$ for both electrolytes. However, after 50 cycles (Figure S10 and S11), the cathode structure (full discharge state) in conventional electrolyte becomes a mixed phase of O3/P3 while it in advanced electrolyte is still O3. The $50^{\text {th }}$ cycle ex-situ XRD obtained in the conventional electrolyte does not show reversible peak shift similar to that in the advanced electrolyte (Figure S10 and S11). Hence, the cathode phase transition/structure in conventional electrolyte has poor reversibility. 

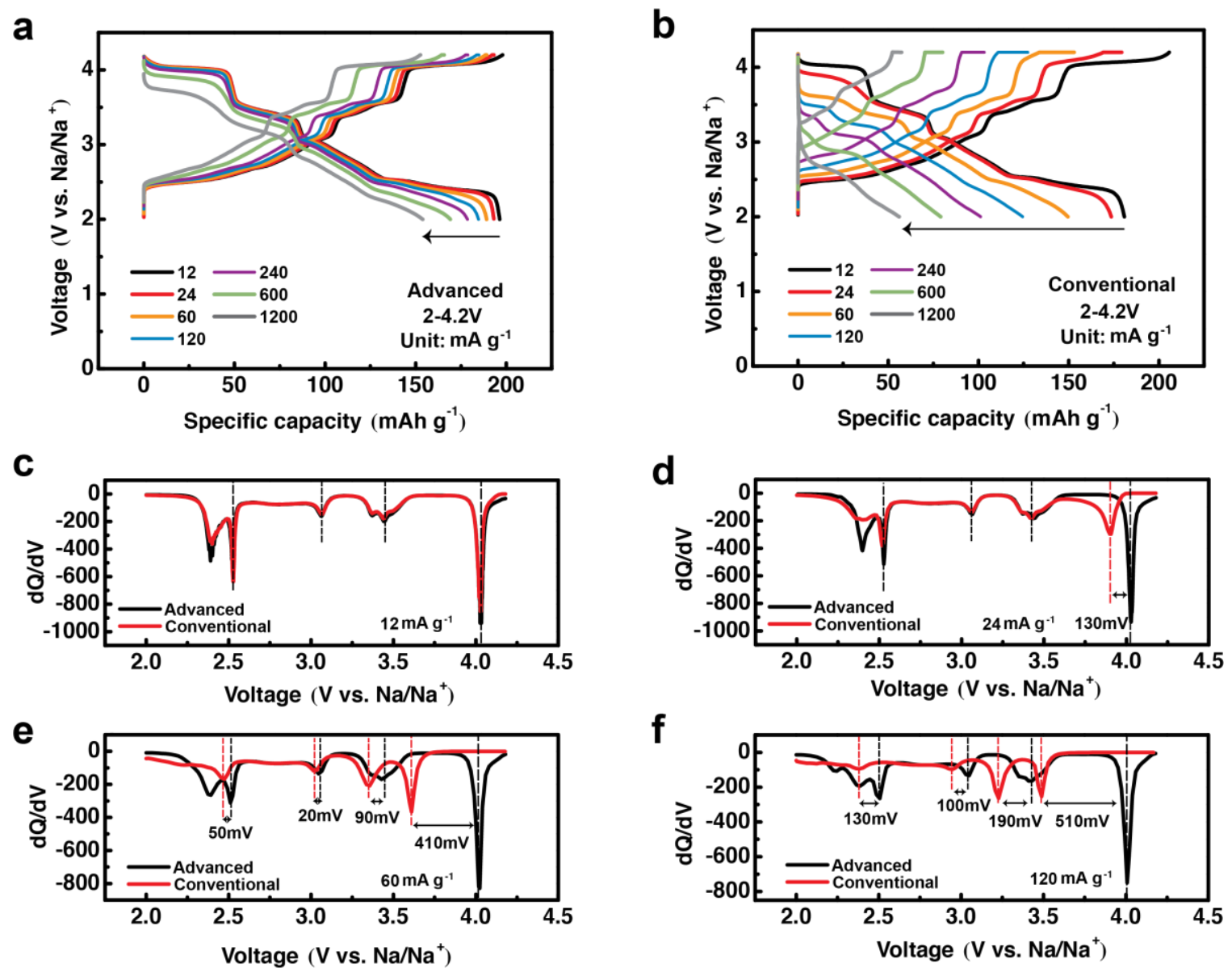

Figure S12. Electrochemical analyses of the O3-NaNMC682210 cycled between 2-4.2V. a, Charge/discharge curves at different current densities in advanced electrolyte. $\mathbf{b}$, Charge/discharge curves at different current densities in conventional electrolyte. c-f, Comparison of dQ/dV plots derived from $\mathbf{a}$ and $\mathbf{b}$ at current densities of $12 \mathrm{~mA} \mathrm{~g}^{-1}$ (c), $24 \mathrm{~mA} \mathrm{~g}^{-1}$ (d), $60 \mathrm{~mA} \mathrm{~g}^{-1}$ (e) and 120 $\mathrm{mA} \mathrm{g}^{-1}(\mathbf{f})$.

The discharge capacity of O3-NaNMC682210 at low current density (12 $\left.\mathrm{mA} \mathrm{g}^{-1}\right)$ are similar in advanced and conventional electrolytes $(\mathbf{a}, \mathbf{b})$. However, the capacity and average potential deviate sharply from each other with the increase of current density, especially for the high voltage plateau of $4-4.2 \mathrm{~V}$. According to the $\mathrm{dQ} / \mathrm{dV}$ plots, the high voltage peak position at $\sim 4 \mathrm{~V}$ is more sensitive to the current density increment in conventional than in advanced electrolyte. At $12 \mathrm{~mA} \mathrm{~g}^{-1}$, no potential difference was observed for the $4 \mathrm{~V}$ peak (c). As the current density increases, the peak potential differences become obvious, which are $130 \mathrm{mV}, 410 \mathrm{mV}$ and $510 \mathrm{mV}$, at $24 \mathrm{~mA} \mathrm{~g}^{-1}, 60$ $\mathrm{mA} \mathrm{g}^{-1}$ and $120 \mathrm{~mA} \mathrm{~g}^{-1}$, respectively (c-f). In addition to the receding peak position, the intensity of the $\mathrm{dQ} / \mathrm{dV}$ peak at high voltage also drastically weakens, indicating a kinetically retarded phase transition at high rate. The shortened high voltage phase also seems to worsen the stability of the low voltage plateau of $2-2.5 \mathrm{~V}$, where two characteristic peaks at $\sim 2.3$ and $\sim 2.5 \mathrm{~V}$ gradually phase out at high current densities. The potential discrepancies in the middle range $(3.0-3.5 \mathrm{~V})$ are relatively small and less affected by the rate, with the largest difference of $190 \mathrm{mV}$ occurs at 120 $\mathrm{mA} \mathrm{g}^{-1}$. The charge/discharge profiles and dQ/dV analyses suggest that the phase transition of O3- 
NMC682210 between $4-4.2 \mathrm{~V}$ is kinetically controlled and can be regulated by tuning the electrolyte. ${ }^{6}$

a

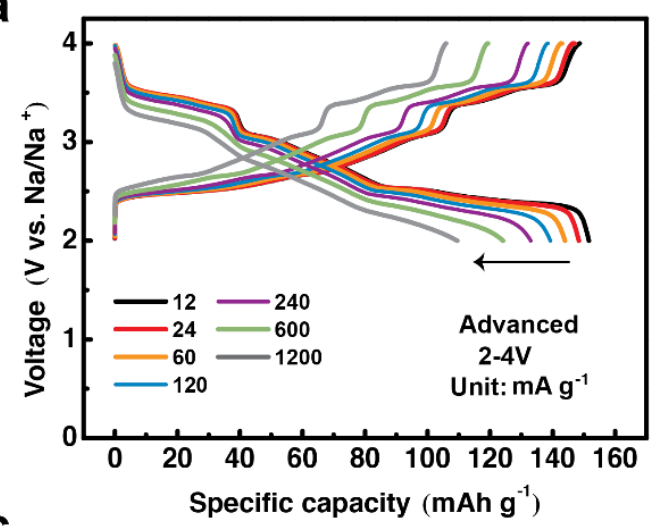

C

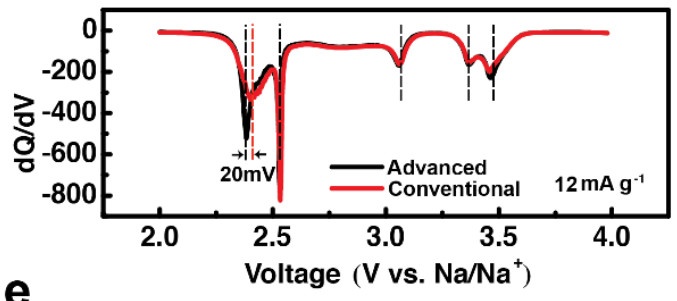

e

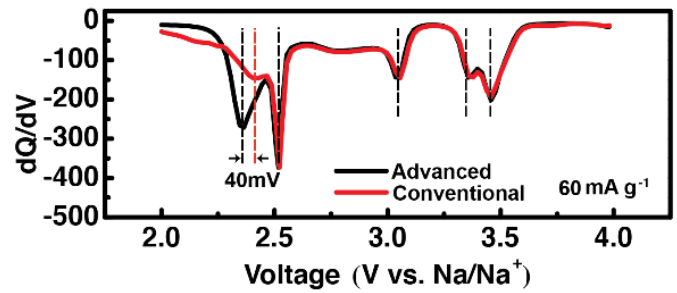

b

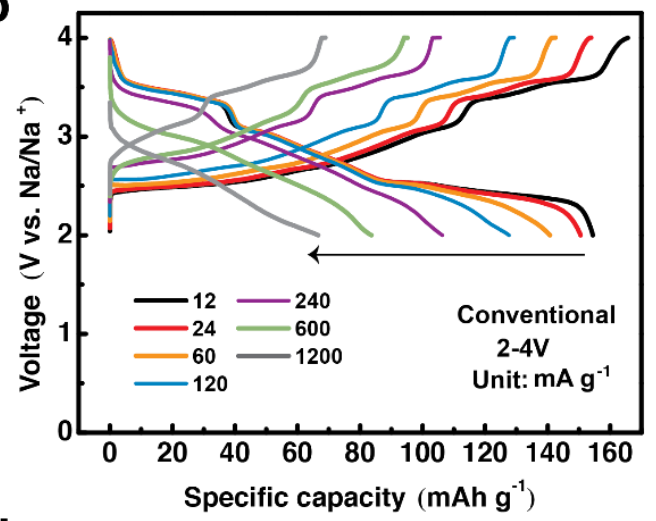

d

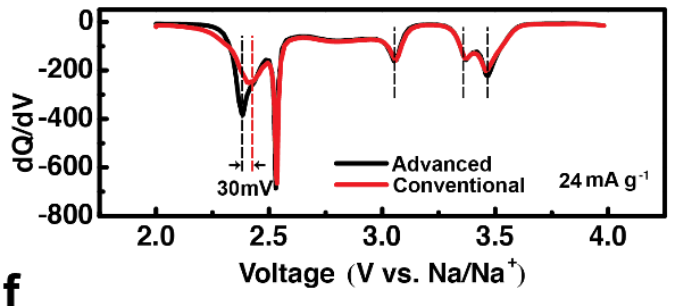

f

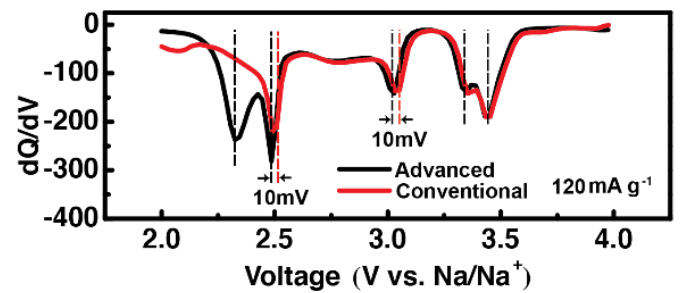

Figure S13. Electrochemical analyses of the O3-NaNMC682210 cycled between 2-4V. a, Charge/discharge curves at different current densities in advanced electrolyte. $\mathbf{b}$, Charge/discharge curves at different current densities in conventional electrolyte. c-f, Comparison of dQ/dV plots derived from $\mathbf{a}$ and $\mathbf{b}$ at current density of $12 \mathrm{~mA} \mathrm{~g}^{-1}$ (c), $24 \mathrm{~mA} \mathrm{~g}^{-1}$ (d), $60 \mathrm{~mA} \mathrm{~g}^{-1}$ (e) and $120 \mathrm{~mA}$ $\mathrm{g}^{-1}(\mathbf{f})$.

The discharge capacity at low current density $\left(12 \mathrm{~mA} \mathrm{~g}^{-1}\right)$ are close in advanced and conventional electrolytes (a,b). The lack of high voltage plateau with the $4 \mathrm{~V}$ cut-off voltage leads to less changes to the voltage profiles at different current densities. However, the absence of high voltage phase transition (4-4.2V, Figure S12) does not circumvent the kinetically slow phase transition at the low plateau region of $2-2.5 \mathrm{~V}$. The capacity and potential of the low voltage region have obvious changes with increasing rate in conventional electrolyte. According to the $\mathrm{dQ} / \mathrm{dV}$ plots, the peak position at $\sim 2.3 \mathrm{~V}$ is more vulnerable to the increasing current density in conventional electrolyte than in advanced electrolyte. At $12 \mathrm{~mA} \mathrm{~g}^{-1}$, a potential difference of $\sim 20 \mathrm{mV}$ is observed for the peak at $\sim 2.3 \mathrm{~V}(\mathbf{c})$. As the current density increases, the potential differences become obvious, 
which are $30 \mathrm{mV}$ and $40 \mathrm{mV}$ at $24 \mathrm{~mA} \mathrm{~g}^{-1}$ and $60 \mathrm{~mA} \mathrm{~g}^{-1}$, respectively (d-e). The peak at $\sim 2.3 \mathrm{~V}$ has completely vanished at $120 \mathrm{~mA} \mathrm{~g}^{-1}$ in conventional electrolyte (f). In advanced electrolyte, even though the peak intensities decrease at high current densities, the shape of peak is distinctively visible with negligible position movement. Similar to Figure S11, the potential discrepancies in the middle range $(3.0-3.5 \mathrm{~V})$ are relatively small and less affected by the current rate, with the largest difference of $10 \mathrm{mV}$ at $120 \mathrm{~mA} \mathrm{~g}^{-1}$. Overall, the kinetics of phase transition between $2-4 \mathrm{~V}$ is mainly associated with the low plateau region, which further corroborates the importance of kinetic control for achieving good phase reversibility. ${ }^{6}$

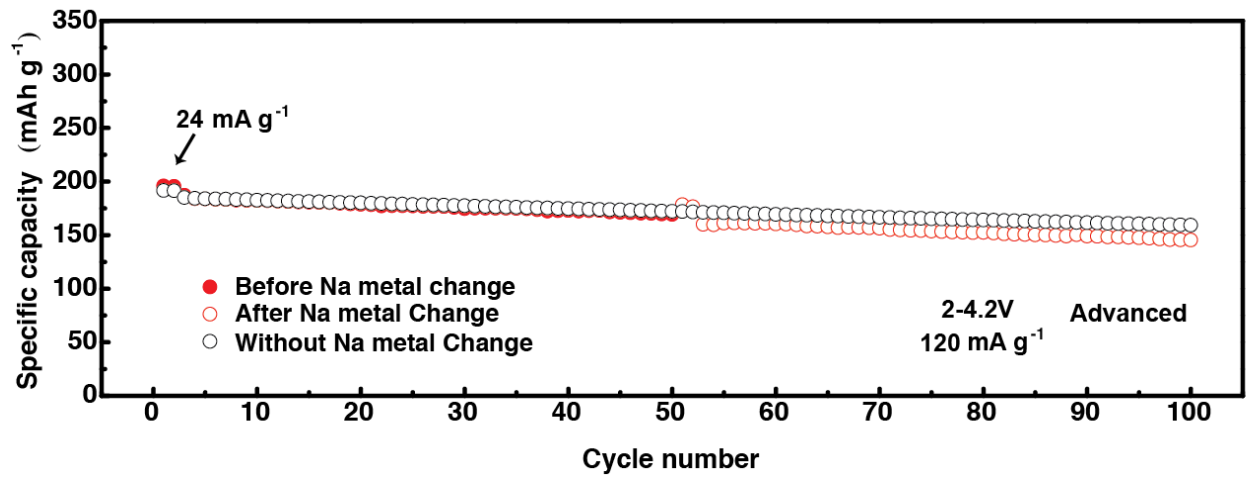

Figure S14. Cycling performance of O3-NaNMC682210 half-cells with or without applying a new piece of $\mathrm{Na}$ metal after 50 cycles. The cell is cycled between $2-4.2 \mathrm{~V}$ in advanced electrolyte. 

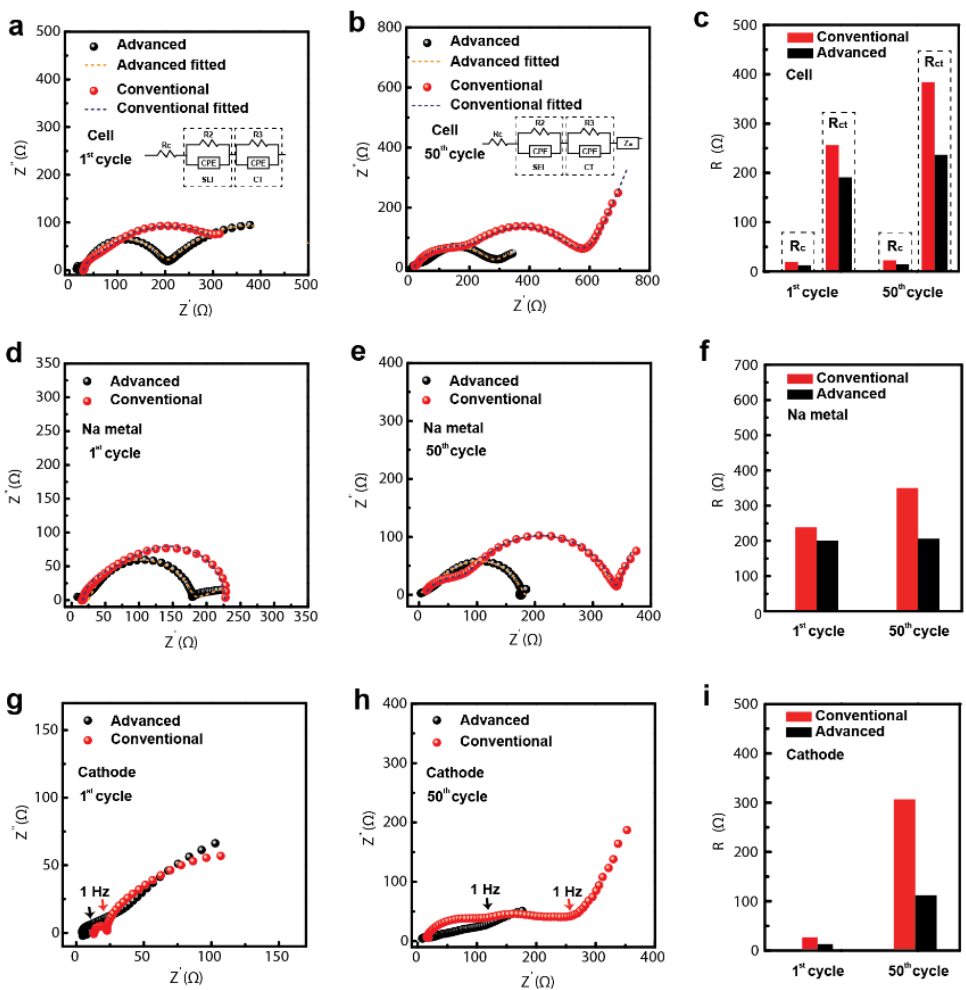

Figure S15. Three-electrode EIS of the cells with conventional and advanced electrolyte. $a-b$, Cell impedance spectra of $1^{\text {st }}$ (a) and $50^{\text {th }}$ (b). c, Bar chart showing the side-by-side comparison of the impedance obtained from a,b. d-e, Na metal impedance spectra of $1^{\text {st }}(\mathrm{d})$ and $50^{\text {th }}(\mathrm{e})$. f, Bar chart showing the side-by-side comparison of the impedance obtained from d,e. g-h, Cathode impedance spectra of $1^{\text {st }}(\mathrm{g})$ and $50^{\text {th }}(\mathrm{h})$. i, Bar chart showing the side-by-side comparison of the impedance obtained from $\mathbf{g}, \mathbf{h}$.

The 3-electrode EIS were analyzed at discharge state of the cells with cathode as the working electrode, $\mathrm{Na}$ metal as the counter electrode and lithium titanate as the reference electrode. The cell impedance increase mainly comes from the interface charge-transfer resistance for the $50^{\text {th }}$ cycle sample. Analysis of the impedance at the cathode and the anode shows that the impedance difference of the two systems after cycling is mostly from the cathode side. At the initial cycle, the cathodes show comparable impedance in the two electrolytes and the impedance of the cell with conventional electrolyte is slightly larger than the cell with advanced electrolyte. After 50 cycles, the impedance increase of the cathode in conventional electrolyte becomes apparent in the chargetransfer region, which is directly related the retarded $\mathrm{Na}^{+}$migration due to the thickening rock salt layer. 

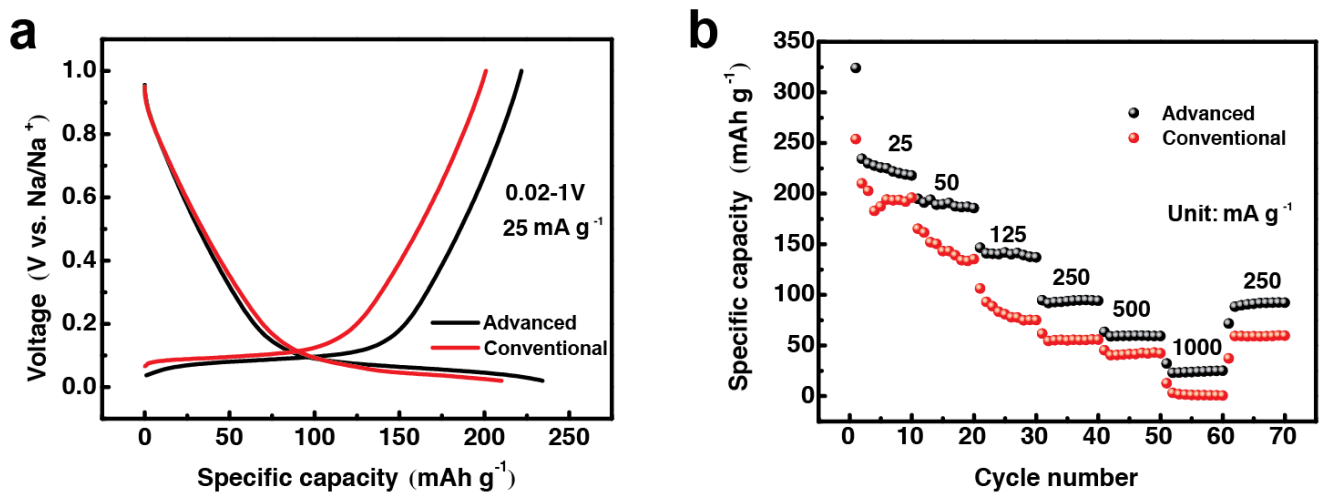

Figure S16. Electrochemical performance of hard carbon anodes in advanced and conventional electrolytes between $\mathbf{0 . 0 2 - 1 V}$. a, Typical charge/discharge curves at $25 \mathrm{~mA} \mathrm{~g}^{-1}$. b, Rate performance.
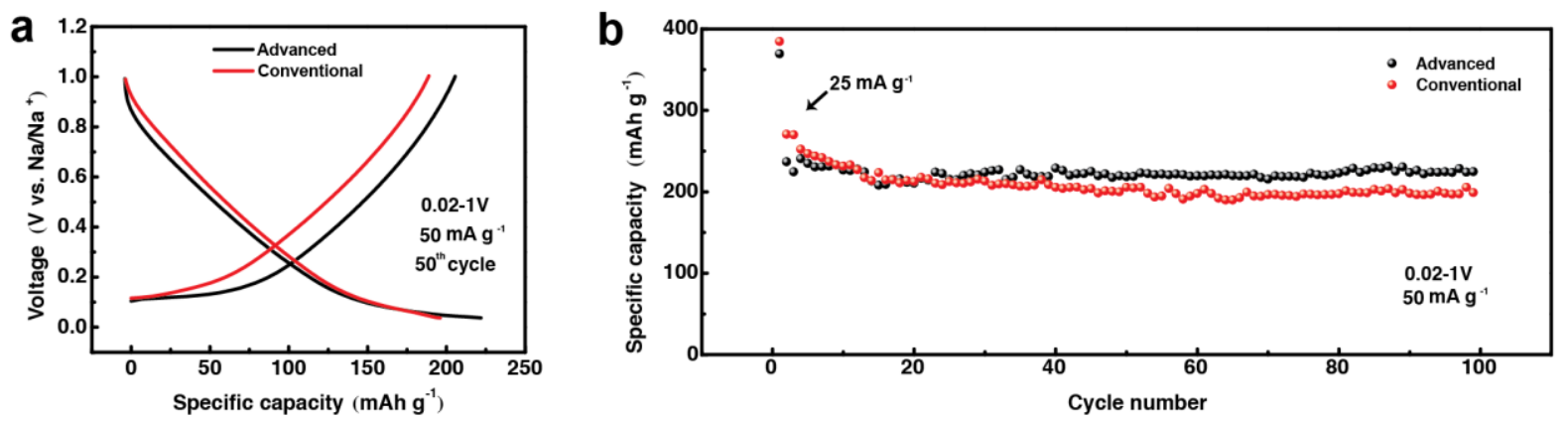

Figure S17. Electrochemical performance of hard carbon anodes in conventional and advanced electrolytes. a, Typical charge/discharge curves at $50 \mathrm{~mA} \mathrm{~g}^{-1}$. b, Cycling performance at $50 \mathrm{~mA} \mathrm{~g}^{-1}$. 

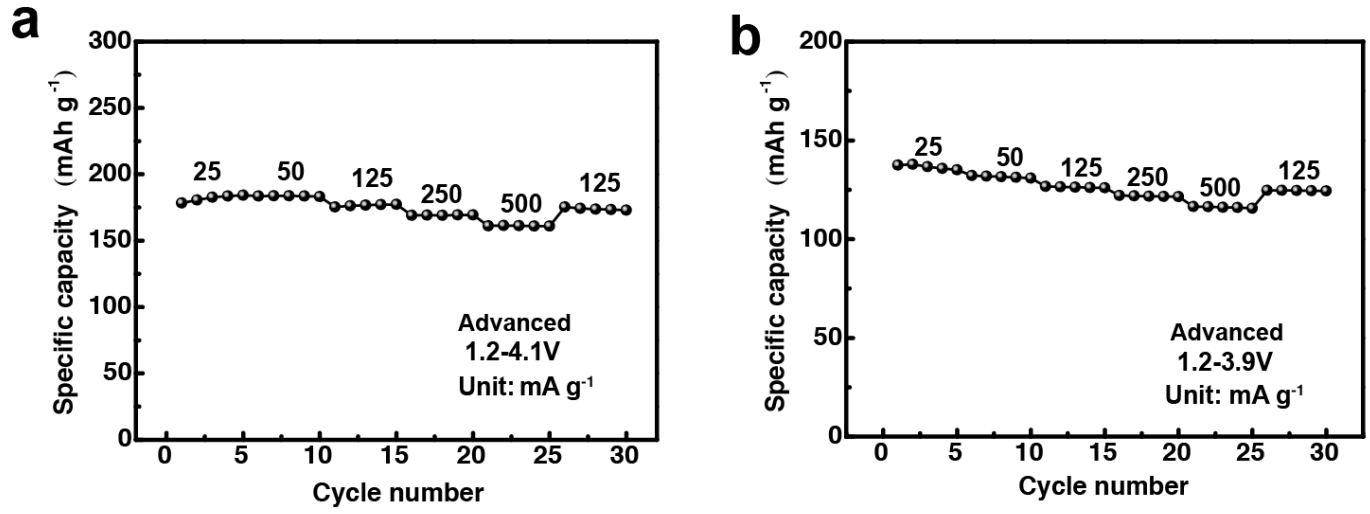

Figure S18. Rate performance of O3-NaNMC682210-hard carbon full-cells in advanced electrolytes. a, Rate performance between 1.2-4.1 V. b, Rate performance between 1.2-3.9V. 

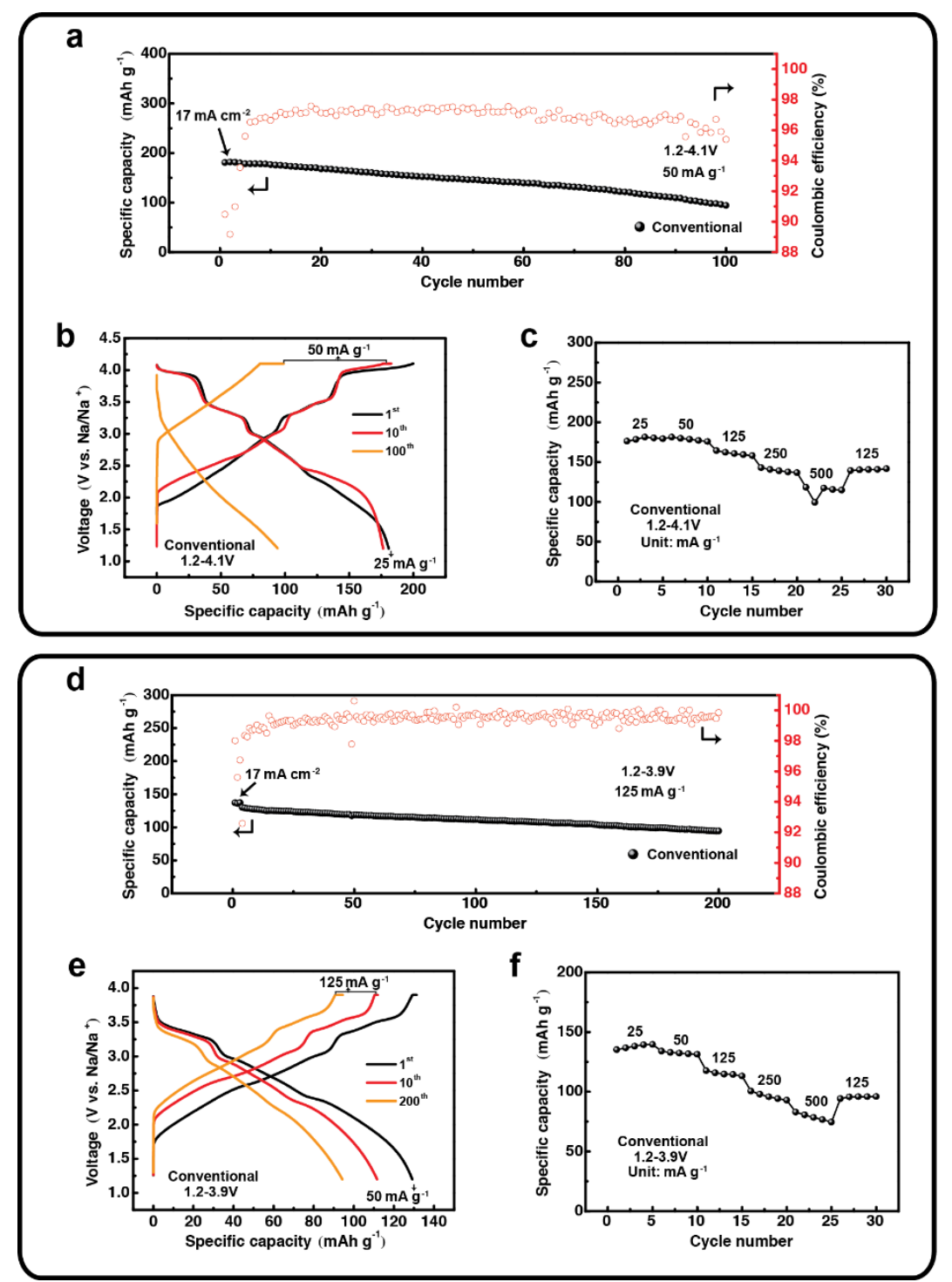

Figure S19. Electrochemical performance of O3-NMC682210-hard carbon full-cells in conventional electrolyte. (a) Cycling performance, (b) charge/discharge curves and (c) rate performance between $1.2-4.1 \mathrm{~V}$. The capacity retention of the cell in a after 100 cycles is $52 \%$. (d) Cycling performance, (e) charge/discharge curves and (f) rate performance between 1.2-3.9V. The capacity retention of the cell in $\mathbf{d}$ after 200 cycles is $73 \%$. 

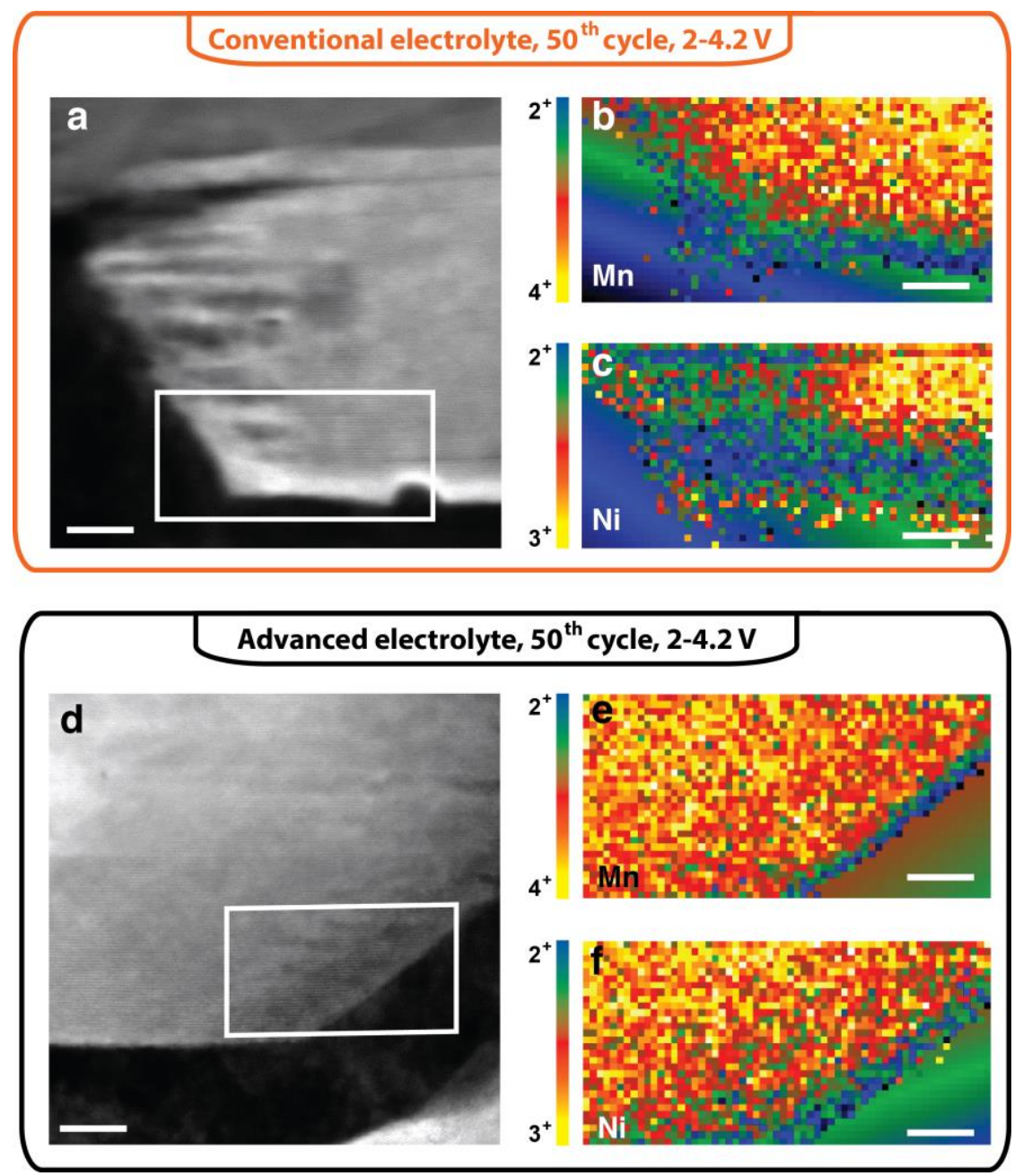

Figure S20. STEM-HAADF and corresponding EELS valence state mappings of the O3NaNMC682210 cathodes after 50 cycles between 2-4.2V. a-c, Conventional electrolyte. a, A typical STEM-HAADF image; Scale bar: 20nm. b, Mn EELS mappings. c, Ni EELS mapping; Scale bars: $5 \mathrm{~nm}$. d-f, Advanced electrolyte. d, A typical STEM-HAADF image; Scale bar: 20nm. e, Mn EELS mapping. f, Ni EELS mapping; Scale bars: 5nm. 

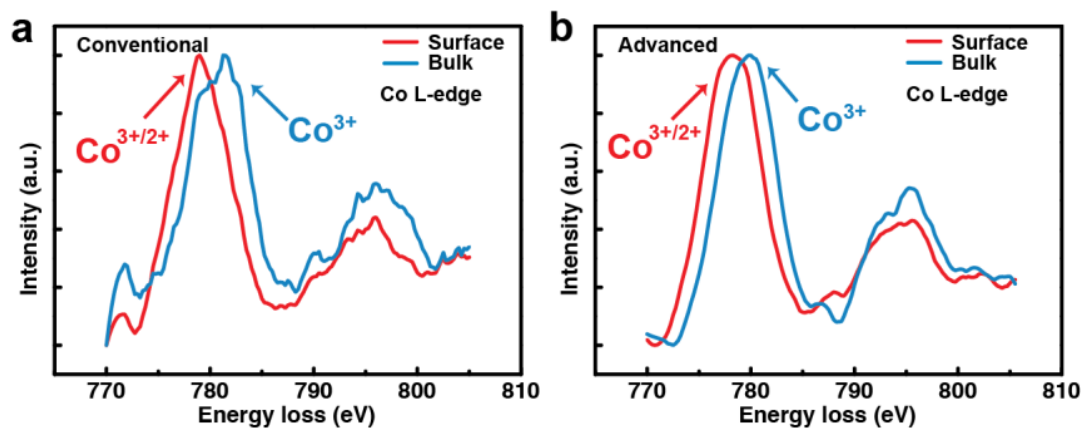

Figure S21. EELS spectra showing the Co valence states at the bulk and surface of the O3NaNMC682210 cathodes after 50 cycles between 2-4.2V. a, Conventional electrolyte. b, Advanced electrolyte.
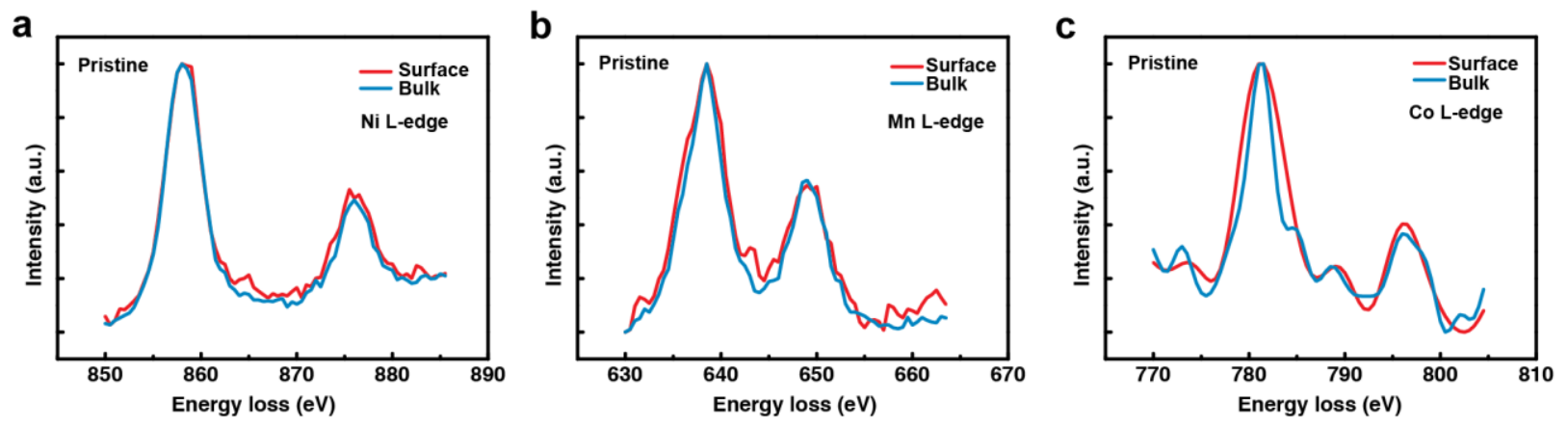

Figure S22. EELS spectra showing the valence states of transition metals at the bulk and surface of a pristine O3-NaNMC682210 cathode. a, Ni L-edge. b, Mn L-edge. c, Co L-edge. 

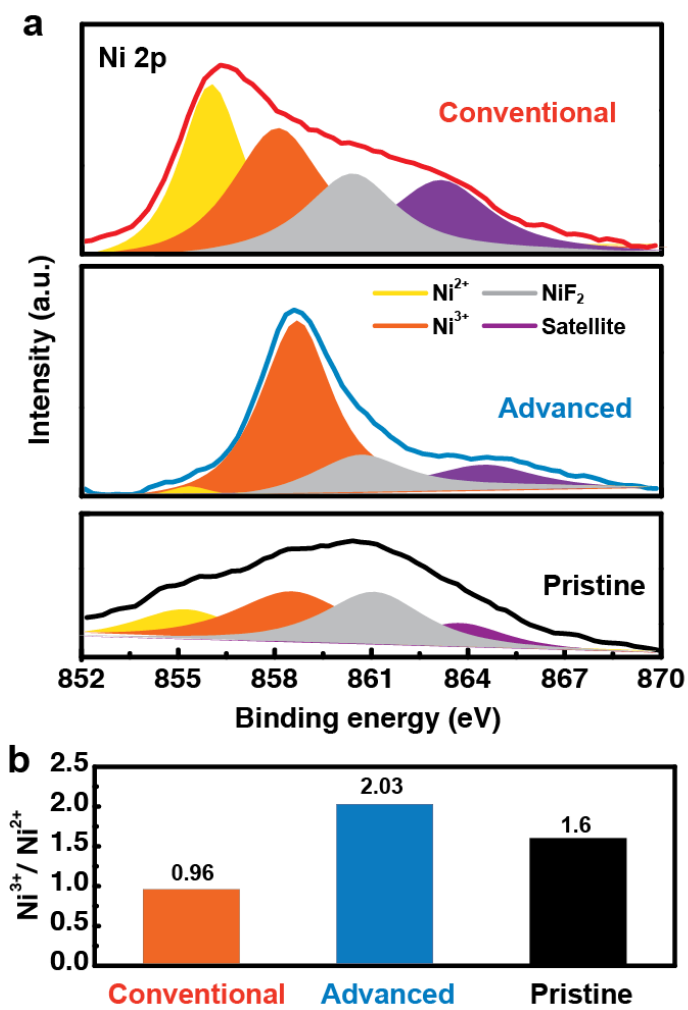

Figure S23. a, Ni 2p XPS spectra of the pristine O3-NaNMC682210 cathode and cathode after 50 cycles between $2-4.2 \mathrm{~V}$ in conventional and advanced electrolyte. $\mathbf{b}$, Bar chart of the $\mathrm{Ni}^{3+} / \mathrm{Ni}^{2+}$ ratio obtained from the deconvoluted peak areas in $\mathbf{a}$.

The $\mathrm{Ni}^{3+} / \mathrm{Ni}^{2+}$ ratios are 0.96 and 2.03 for cathodes cycled in conventional and advanced electrolyte, respectively, and 1.6 for pristine cathode. The $\mathrm{Ni}^{3+} / \mathrm{Ni}^{2+}$ ratio of cycled cathode in advanced electrolyte is $\sim 2.1$ and $\sim 1.2$ times of that in conventional electrolyte and pristine cathode, respectively. 

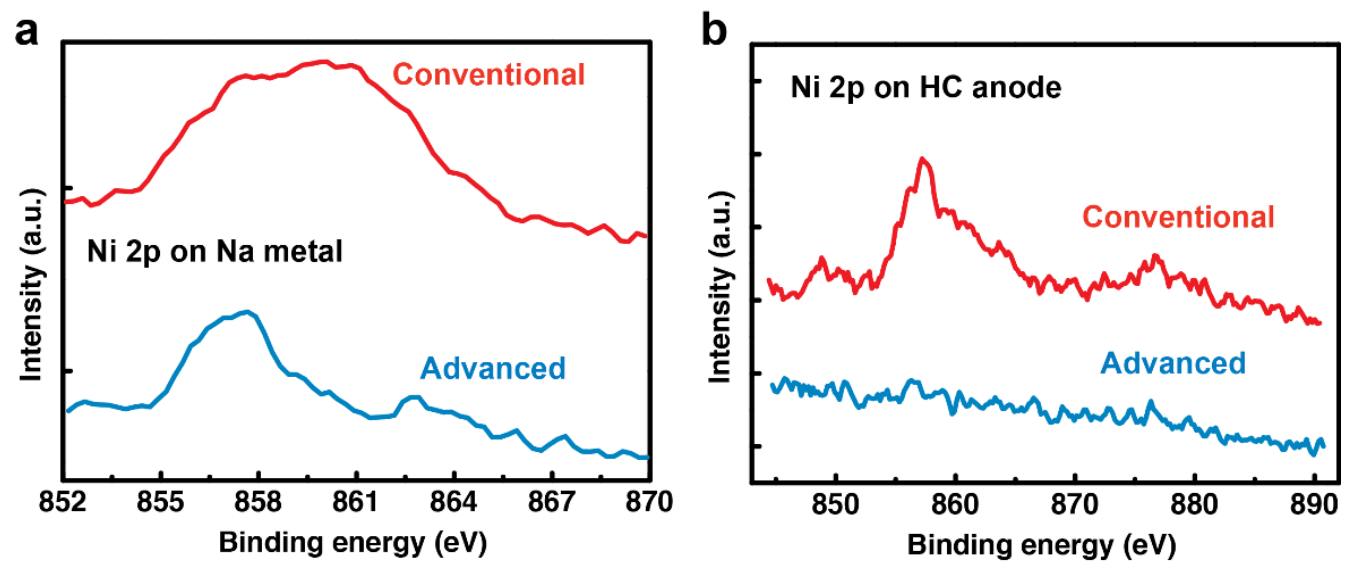

Figure S24. Ni 2p XPS taken at the counter electrodes of O3-NaNMC682210 half-cells and full-cells after 50 cycles. a, Na metals acquired from half-cells operated between 2-4.2V. b, Hard carbon anodes acquired from full-cells operated between 1.2-4.1V.
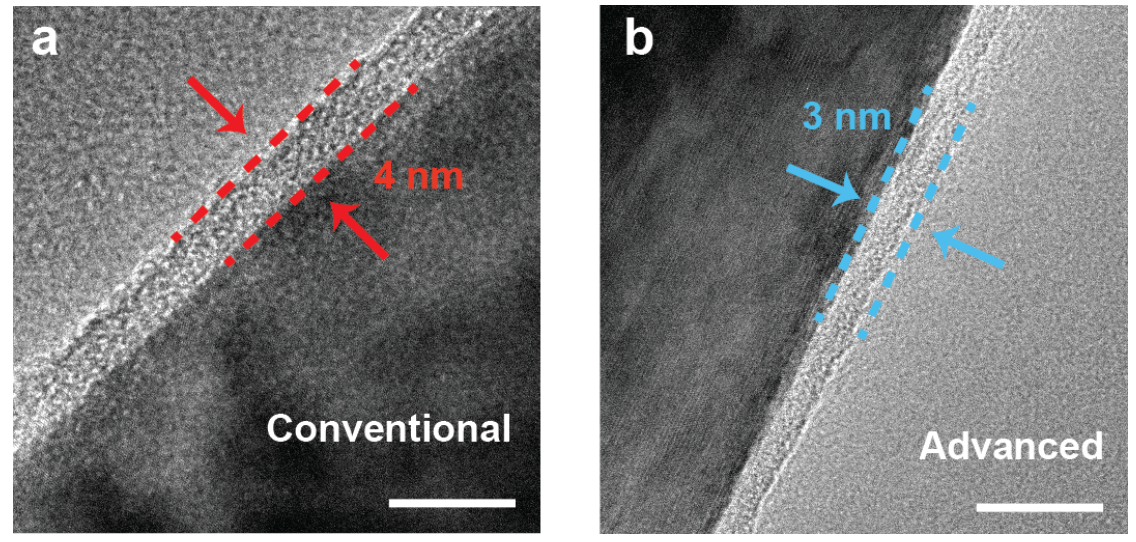

Figure S25. TEM images of the CEI layers obtained on the O3-NaNMC682210 cathode surface after 50 cycles between $2-4.2 \mathrm{~V}$. a, Conventional electrolyte. b, Advanced electrolyte. Scale bars: $10 \mathrm{~nm}$. 

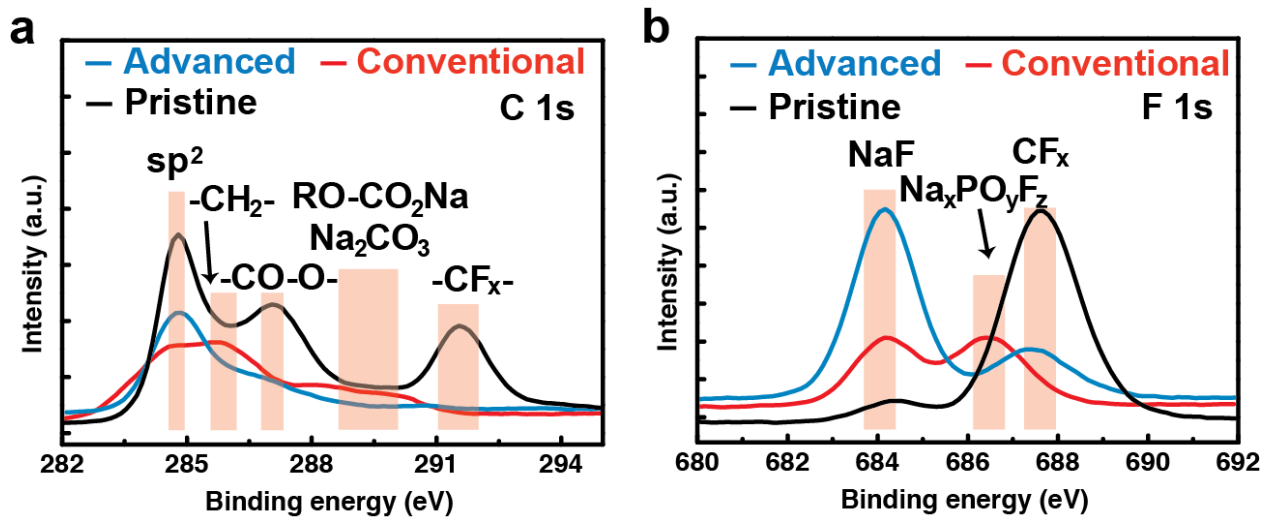

Figure S26. XPS analyses of the CEI layers of O3-NaNMC682210 cathodes after 50 cycles between of $2-4.2 \mathrm{~V}$ in advanced and conventional electrolytes. a, $\mathrm{C} 1 \mathrm{~s}$ spectra. b, F 1s spectra.

The $\mathrm{C}$ 1s spectrum of the pristine cathode (black curve in a) shows a strong peak at $284.5 \mathrm{eV}$ corresponding to the $\mathrm{sp}^{2} \mathrm{C}-\mathrm{C}$ bond from the carbon additive. ${ }^{9}$ Other peaks at $286.2 \mathrm{eV}, 287.1 \mathrm{eV}$ and $291.5 \mathrm{eV}$ are associated with various functional groups from the carbon additive and PVDF binder, including $-\mathrm{CH}_{2}-$, $-\mathrm{CO}-\mathrm{O}-$ and $-\mathrm{CF}_{2}-{ }^{7}$ The $-\mathrm{CF}_{2}$ - peak disappears in the cycled electrodes due to the coverage of the CEI layer. The electrolyte decomposition products are similar in both electrolytes with slightly higher ratio of $-\mathrm{CH}_{2}-$, alkyl carbonate $\left(\mathrm{ROCO}_{2} \mathrm{Na}\right)$ and carbonate $\left(\mathrm{Na}_{2} \mathrm{CO}_{3}\right)$ in conventional electrolyte than in advanced electrolyte. The $\mathrm{F} 1 \mathrm{~s} \mathrm{~s}$ spectrum of the pristine cathode shows a strong $-\mathrm{CF}_{2}$ - peak at $687.4 \mathrm{eV}$ from the PVDF binder, while the cycled cathodes have strong $\mathrm{NaF}$ signals at $684.1 \mathrm{eV}$ from the CEI formation. ${ }^{10}$ The $\mathrm{NaF} / \mathrm{CF}_{\mathrm{x}}$ ratio is higher in advanced electrolyte than in conventional electrolyte. The peak at $686.5 \mathrm{eV}$ in conventional electrolyte is assigned to the decomposition production from the $\mathrm{NaPF}_{6}$ salt. $^{8}$
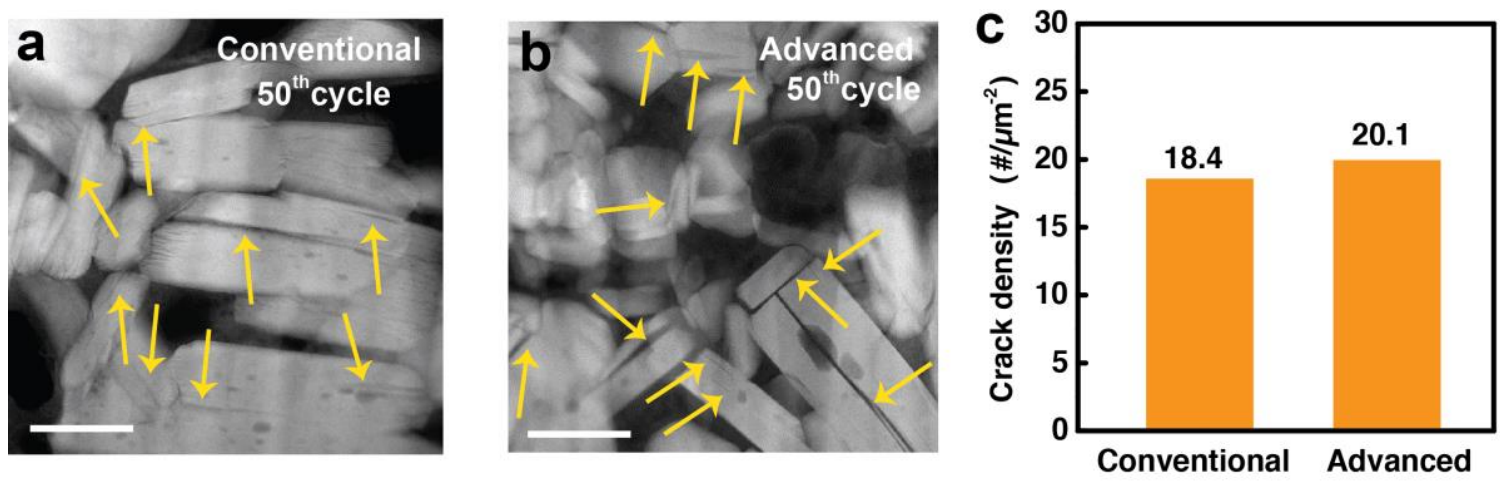

Figure S27. STEM images and histogram showing the intragranular cracking of O3NaNMC682210 cathodes after 50 cycles between 2-4.2V. a, A typical STEM image of the cathode after cycling in conventional electrolyte. Scale bar: $200 \mathrm{~nm}$. b, A typical STEM image of the cathode after cycling in advanced electrolyte. The yellow cursors point out the locations of the intragranular cracks. Scale bar: $200 \mathrm{~nm}$. c, Histogram plot showing the crack density in conventional and advanced electrolyte. 

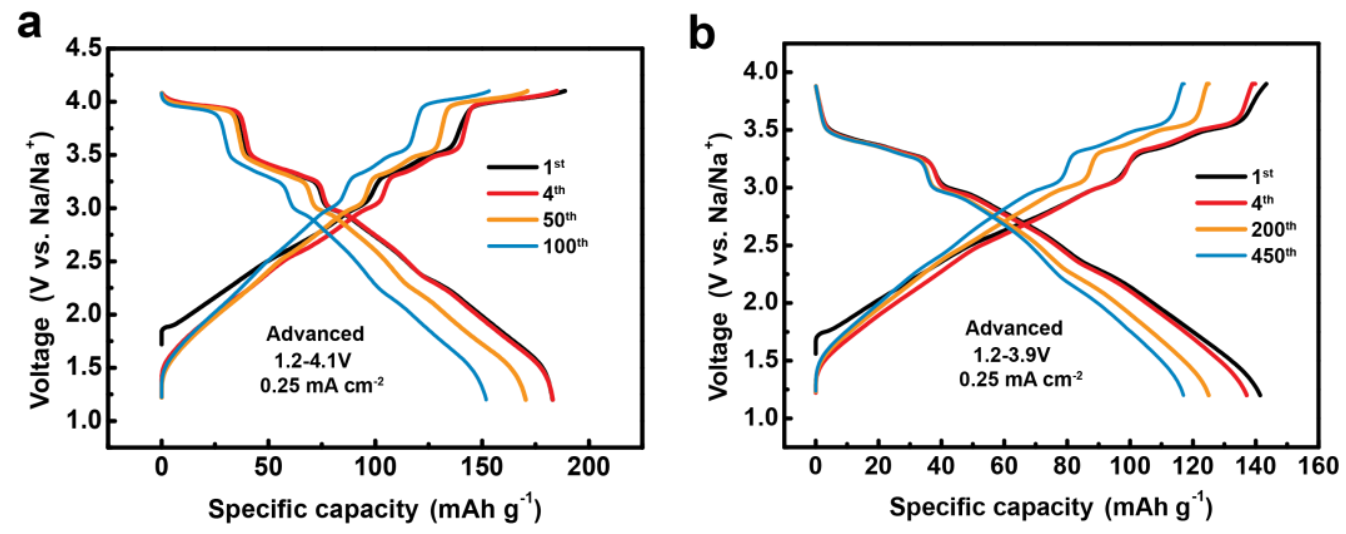

Figure S28. Charge/discharge curves of high loading O3-NaNMC682210-hard carbon fullcells. a, Charge/discharge curves of the cell in Figure 4a. b, Charge/discharge curves of the cell in Figure 4b.

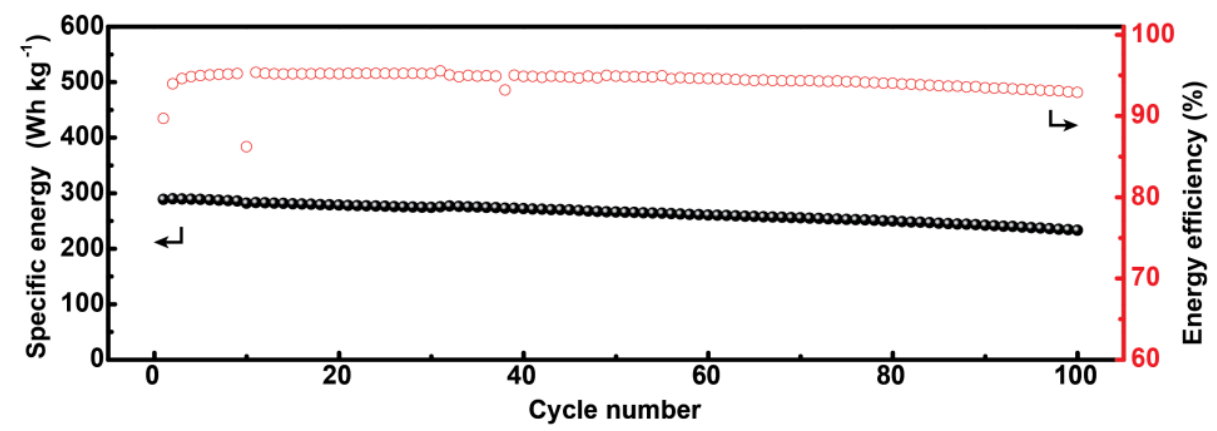

Figure S29 Specific energy (based on the weight of cathode and anode) and energy efficiency of the O3-NaNMC682210-hard carbon full-cell in Figure 4a. 
a

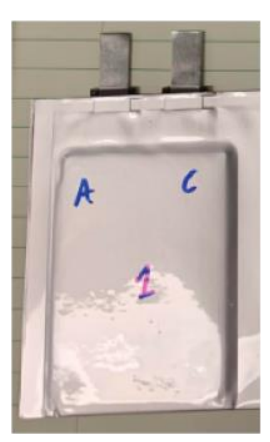

C

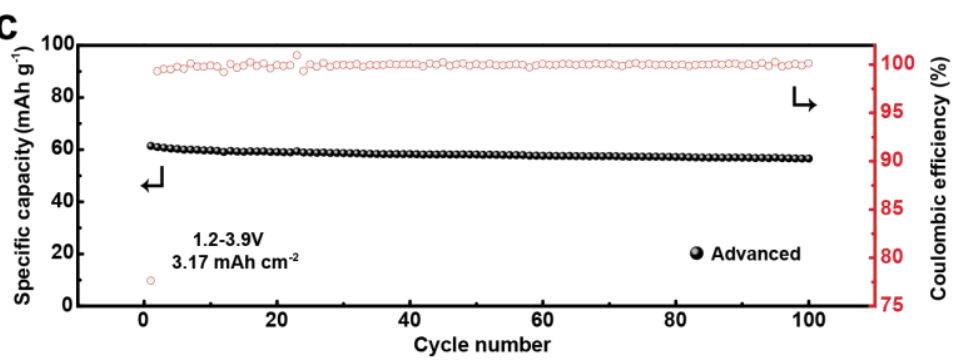

b

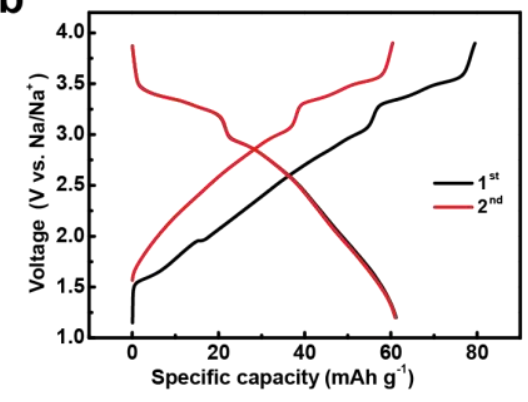

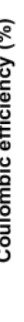

Figure S30. Electrochemical performance of $60 \mathrm{mAh}$ O3-NaNMC682210-hard carbon pouch cell. a, A photo of the $60 \mathrm{mAh}$ pouch cell. b, Typical charge-discharge curves. c, Cycling performance with the voltage range of $1.2-3.9 \mathrm{~V}$ in advanced electrolyte. 

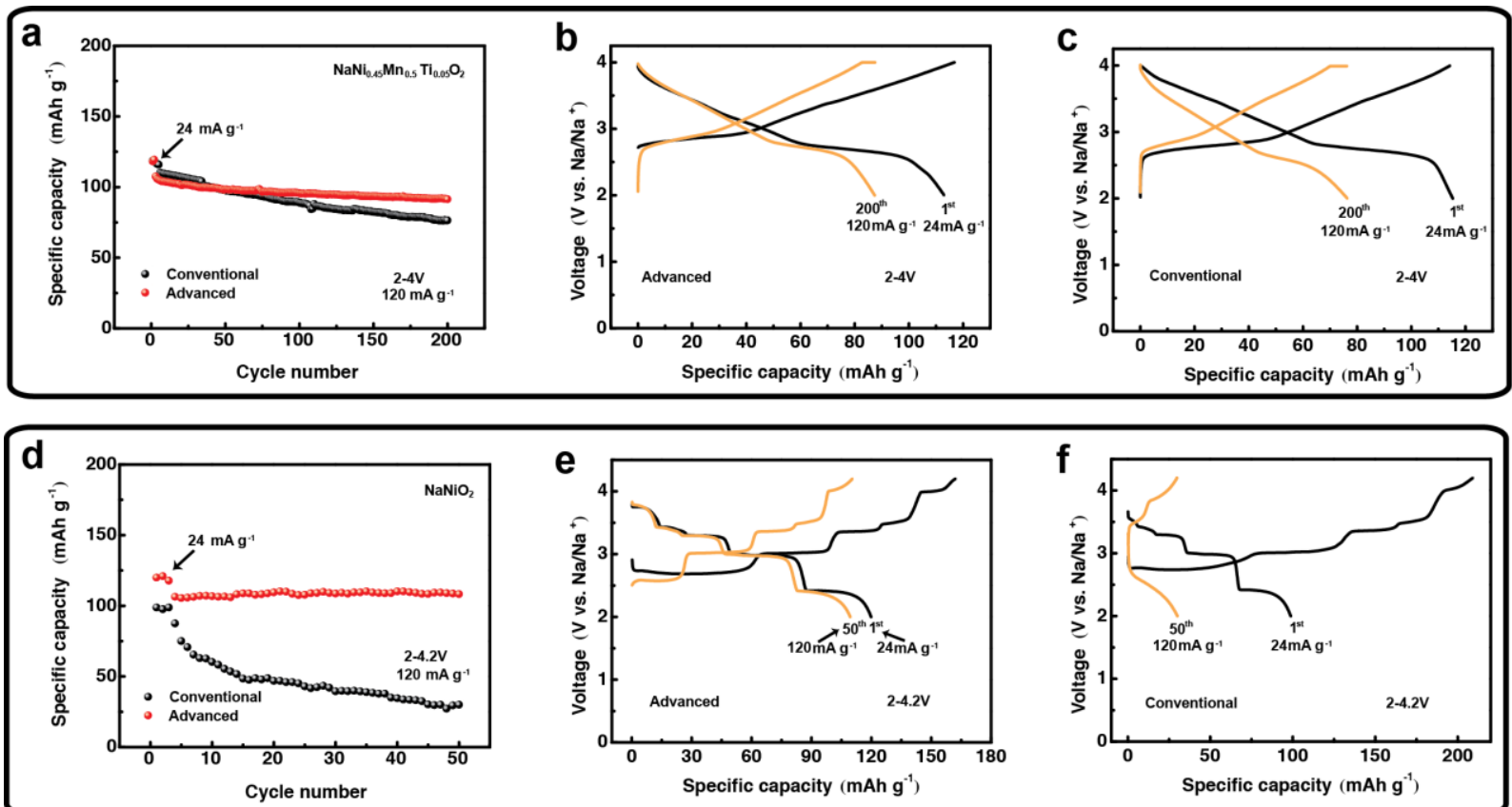

Figure S31. Electrochemical performance of other O3-type SIB cathodes in advanced and conventional electrolyte. a, $\mathrm{NaNi}_{0.45} \mathrm{Mn}_{0.5} \mathrm{Ti}_{0.05} \mathrm{O}_{2}$ cathode cycled between $2-4 \mathrm{~V}$ at a current density of $120 \mathrm{~mA} \mathrm{~g}^{-1}$. The capacity retention in advanced electrolyte is $86 \%$ after 200 cycles, much higher than the $65 \%$ in conventional electrolyte. b-c, Charge/discharge curves of the cells in $\mathbf{a}$ in advanced (b) and conventional (c) electrolyte. $\mathbf{d}, \mathrm{NaNiO}_{2}$ cathode cycled between $2-4.2 \mathrm{~V}$ at a current density of $120 \mathrm{~mA} \mathrm{~g}^{-1}$. The capacity retention in advanced electrolyte is $\sim 99 \%$ after 50 cycles, much higher than the $34 \%$ in conventional electrolyte. e-f, Charge/discharge curves of the cells in $\mathbf{d}$ in advanced (e) and conventional (f) electrolyte. 
Table S1| The Na cathode performance in half- and full-cells from literature and our work.

\begin{tabular}{|c|c|c|c|}
\hline Reference & Half-Cell Performance & Full-Cell Performance & Cathode Type \\
\hline (9) & $\begin{array}{l}175 \mathrm{mAh} \mathrm{g}^{-1}\left(10 \mathrm{~mA} \mathrm{~g}^{-1}, 2-\right. \\
4.5 \mathrm{~V}),>94 \% \text { retention at } 50^{\text {th }} \\
\text { cycles at } 10 \mathrm{~mA} \mathrm{~g}^{-1} \text {. }\end{array}$ & NA & $\begin{array}{l}\text { P2 layered } \\
\text { metal oxides }\end{array}$ \\
\hline$(10)$ & $\begin{array}{l}170 \mathrm{mAh} \mathrm{g}^{-1}\left(12 \mathrm{~mA} \mathrm{~g}^{-1}, 2-4 \mathrm{~V}\right) \\
81 \% \text { retention at } 400^{\text {th }} \text { cycle at } \\
120 \mathrm{~mA} \mathrm{~g}^{-1} .\end{array}$ & $\begin{array}{l}215 \mathrm{Wh} \mathrm{kg}^{-1}, 1.01-4.19 \mathrm{~V}, \\
66 \% \text { capacity retention at } \\
100^{\text {th }} \text { cycle at } 120 \mathrm{~mA} \mathrm{~g}^{-1} .\end{array}$ & $\begin{array}{l}\text { O3 layered } \\
\text { metal oxides }\end{array}$ \\
\hline (11) & $\begin{array}{l}124 \mathrm{mAh} \mathrm{g}^{-1}\left(12 \mathrm{~mA} \mathrm{~g}^{-1}, 2-4 \mathrm{~V}\right) \text {, } \\
70 \% \text { retention at } 500^{\text {th }} \text { cycle at } \\
120 \mathrm{~mA} \mathrm{~g}^{-1} \text {. }\end{array}$ & NA & $\begin{array}{l}\text { O3 layered } \\
\text { metal oxides }\end{array}$ \\
\hline (12) & $\begin{array}{l}140 \mathrm{mAh} \mathrm{g}^{-1}\left(108 \mathrm{~mA} \mathrm{~g}^{-1}, 2.5-\right. \\
4 \mathrm{~V}), 67 \% \text { retention at } 500^{\text {th }} \\
\text { cycle at } 216 \mathrm{~mA} \mathrm{~g}^{-1} \text {. }\end{array}$ & NA & $\begin{array}{l}\text { O3 layered } \\
\text { metal oxides }\end{array}$ \\
\hline (13) & $\begin{array}{l}124 \mathrm{mAh} \mathrm{g}^{-1}\left(12 \mathrm{~mA} \mathrm{~g}^{-1}, 3-\right. \\
4.3 \mathrm{~V})\end{array}$ & $\begin{array}{l}235 \mathrm{Wh} \mathrm{kg}^{-1}, 2-4.3 \mathrm{~V}, 96 \% \\
\text { capacity retention at } 50^{\text {th }} \\
\text { cycle at } 12 \mathrm{~mA} \mathrm{~g}^{-1} .\end{array}$ & $\begin{array}{l}\text { Phosphate } \\
\text { material }\end{array}$ \\
\hline (14) & $\begin{array}{l}160 \mathrm{mAh} \mathrm{g}^{-1}\left(10 \mathrm{~mA} \mathrm{~g}^{-1}, 2-4 \mathrm{~V}\right), \\
80 \% \text { retention at } 1000^{\text {th }} \text { cycle at } \\
75 \mathrm{~mA} \mathrm{~g}^{-1},\end{array}$ & $\begin{array}{l}119 \mathrm{mAh} \mathrm{g}^{-1} \text { (cathode), } 1- \\
3.8 \mathrm{~V}, 94 \% \text { capacity } \\
\text { retention at } 50^{\text {th }} \text { cycle at } \\
10 \mathrm{~mA} \mathrm{~g}^{-1} \text {. }\end{array}$ & Prussian white \\
\hline (2) & $\begin{array}{l}157 \mathrm{mAh} \mathrm{g}^{-1}\left(15 \mathrm{~mA} \mathrm{~g}^{-1}, 1.5-\right. \\
4.1 \mathrm{~V}), 84 \% \text { retention at } 100^{\text {th }} \\
\text { cycle at } 75 \mathrm{~mA} \mathrm{~g}^{-1} \text {. }\end{array}$ & $\begin{array}{l}143 \mathrm{mAh} \mathrm{g}^{-1} \\
\text { (cathode), } 1.5-3.9 \mathrm{~V}, 80 \% \\
\text { capacity retention at } 300^{\text {th }} \\
\text { cycle at } 75 \mathrm{~mA} \mathrm{~g}^{-1} \text {. }\end{array}$ & $\begin{array}{l}\text { O3 layered } \\
\text { metal oxides }\end{array}$ \\
\hline$(15)$ & $\begin{array}{l}209 \mathrm{mAh} \mathrm{g}^{-1}\left(90 \mathrm{~mA} \mathrm{~g}^{-1}, 1.5-\right. \\
4 \mathrm{~V}), 75 \% \text { retention at } 100^{\text {th }} \\
\text { cycle at } 160 \mathrm{~mA} \mathrm{~g}^{-1} \text {. }\end{array}$ & NA & Prussian blue \\
\hline (16) & $\begin{array}{l}134 \mathrm{mAh} \mathrm{g}^{-1}\left(12 \mathrm{~mA} \mathrm{~g}^{-1}, 2-\right. \\
4.5 \mathrm{~V}) \text {, } \\
84 \% \text { retention at } 500^{\text {th }} \text { cycle at } \\
120 \mathrm{~mA} \mathrm{~g}^{-1} \text {. }\end{array}$ & NA & $\begin{array}{l}\text { Phosphate } \\
\text { material }\end{array}$ \\
\hline (17) & $\begin{array}{l}190 \mathrm{mAh} \mathrm{g}^{-1}\left(13 \mathrm{~mA} \mathrm{~g}^{-1}, 1.5-\right. \\
4.3 \mathrm{~V}), 80 \% \text { retention at } 30^{\text {th }} \\
\text { cycle at } 13 \mathrm{~mA} \mathrm{~g}^{-1} \text {. }\end{array}$ & NA & $\begin{array}{l}\text { P2 layered } \\
\text { metal oxides }\end{array}$ \\
\hline Our Work & $\begin{array}{l}196 \mathrm{mAh} \mathrm{g}^{-1}\left(24 \mathrm{~mA} \mathrm{~g}^{-1}, 2-\right. \\
4.2 \mathrm{~V}), 83 \% \text { retention at } 100^{\text {th }} \\
\text { cycle at } 24 \mathrm{~mA} \mathrm{~g}^{-1} \text {. } \\
151 \mathrm{mAh} \mathrm{g}^{-1}\left(24 \mathrm{~mA} \mathrm{~g}^{-1}, 2-4 \mathrm{~V}\right) \text {, } \\
80 \% \text { retention at } 1000^{\text {th }} \text { cycle at } \\
120 \mathrm{~mA} \mathrm{~g}^{-1} \text {. }\end{array}$ & $\begin{array}{l}290 \mathrm{Wh} \mathrm{kg}^{-1}, 1.2-4.1 \mathrm{~V}, \\
80 \% \text { capacity retention at } \\
200^{\text {th }} \text { cycle at } 50 \mathrm{~mA} \mathrm{~g}^{-1} \text {. } \\
217 \mathrm{Wh} \mathrm{kg}^{-1}, 1.2-3.9 \mathrm{~V}, \\
81 \% \text { capacity retention at } \\
1000^{\text {th }} \text { cycle at } 125 \mathrm{~mA} \mathrm{~g}^{-} \\
1 .\end{array}$ & $\begin{array}{l}\text { O3 layered } \\
\text { metal oxides }\end{array}$ \\
\hline
\end{tabular}




\section{References}

(1) Zheng, J.; Chen, S.; Zhao, W.; Song, J.; Engelhard, M. H.; Zhang, J. G. Extremely stable sodium metal batteries Enabled by Localized High-Concentration Electrolytes. ACS Energy Lett. 2018, 3, 315-321.

(2) Hwang, J. Y.; Oh, S. M.; Myung, S. T.; Chung, K. Y.; Belharouak, I.; Sun, Y. K. Radially aligned hierarchical columnar structure as a cathode material for high energy density sodium-ion batteries. Nat. Commun. 2015, 6, 6865.

(3) Yabuuchi, N.; Kubota, K.; Dahbi, M.; Komaba, S. Research development on sodium-ion batteries. Chem. Rev. 2014, 114, 11636-11682.

(4) Li, X.; Yan, P.; Engelhard, M. H.; Crawford, A. J.; Viswanathan, V. V.; Wang, C.; Liu, J.; Sprenkle, V. L. The importance of solid electrolyte interphase formation for long cycle stability full-cell Na-ion batteries. Nano Energy 2016, $27,664-672$.

(5) Hwang, J. Y.; Yoon, C. S.; Belharouak, I.; Sun, Y. K. A comprehensive study of the role of transition metals in O3-type layered $\mathrm{Na}\left[\mathrm{Ni}_{\mathrm{x}} \mathrm{Co}_{\mathrm{y}} \mathrm{Mn}_{\mathrm{z}}\right] \mathrm{O}_{2}(\mathrm{x}=1 / 3,0.5,0.6$, and 0.8$)$ cathodes for sodium-ion batteries. J. Mater. Chem. A 2016, 4, 17952-17959.

(6) Ma, C.; Alvarado, J.; Xu, J.; Clément, R. J.; Kodur, M.; Tong, W.; Grey, C. P.; Meng, Y. S. Exploring oxygen activity in the high energy P2-Type $\mathrm{Na}_{0.78} \mathrm{Ni}_{0.23} \mathrm{Mn}_{0.69} \mathrm{O}_{2}$ Cathode Material for Na-Ion Batteries. J. Am. Chem. Soc. 2017, 139, 4835-4845.

(7) Komaba, S.; Murata, W.; Ishikawa, T.; Yabuuchi, N.; Ozeki, T.; Nakayama, T.; Ogata, A.; Gotoh, K.; Fujiwara, K. Electrochemical $\mathrm{Na}$ insertion and solid electrolyte interphase for hard-carbon electrodes and application to Na-ion batteries. Adv. Funct. Mater. 2011, 21, 3859-3867.

(8) Bodenes, L.; Darwiche, A.; Monconduit L.; Martinez, H. The solid electrolyte interphase a key parameter of the high performance of Sb in sodium-ion batteries: comparative X-ray photoelectron spectroscopy study of $\mathrm{Sb} / \mathrm{Na}$-ion and $\mathrm{Sb} / \mathrm{Li}$-ion batteries. J. Power Sources 2015, 273, 14-24.

(9) Maitra, U.; House, R. A.; Somerville, J. W.; Tapia-Ruiz, N.; Lozano, J. G.; Guerrini, N.; Hao, R.; Luo, K.; Jin, L.; Pérez-Osorio, M. A.; Massel, F.; Pickup, D. M.; Ramos, S.; Lu, X.; McNally, D. E.; Chadwick, A. V.; Giustino, F.; Schmitt, T.; Duda, L. C.; Roberts, M. R.; Bruce, P. G. Oxygen redox chemistry without excess alkali-metal ions in $\mathrm{Na}_{2 / 3}\left[\mathrm{Mg}_{0.28} \mathrm{Mn}_{0.72}\right] \mathrm{O}_{2}$. Nat. Chem. 2018, 10, 288-295.

(10) Deng, J.; Luo, W.; Lu, X.; Yao, Q.; Wang, Z.; Liu, H. K.; Zhou, H.; Dou, S. X. High energy density sodium-ion battery with industrially feasible and air-stable O3-type layered oxide cathode. Adv. Energy Mater. 2018, 8, 1701610. 
(11) H. R. Yao, P. F. Wang, Y. Gong, J. Zhang, X. Yu, L. Gu, C. Ouyang, Y. X. Yin, E. Hu, X. Q. Yang, E. Stavitski, Y. G. Guo and L. J. Wan, J. Am. Chem. Soc. 2017, $139,8440-8443$.

(12) Yao, H. R.; Wang, P. F.; Gong, Y.; Zhang, J.; Yu, X.; Gu, L.; Ouyang, C.; Yin, Y. X.; Hu, E.; Yang, X. Q.; Stavitski, E.; Guo, Y. G.; Wan, L. J. Designing air-stable O3-type cathode materials by combined structure modulation for Na-ion batteries. J. Am. Chem. Soc. 2017, 139, 8440-8443.

(13) Dugas, R.; Zhang, B.; Rozier, P.; Tarascon, J. M. Optimization of Na-Ion Battery Systems Based on Polyanionic or Layered Positive Electrodes and Carbon Anodes. J. Electrochem. Soc. 2016, 163, A867-A874.

(14) Wang, L.; Song, J.; Qiao, R.; Wray, L. A.; Hossain, M. A.; De Chuang, Y.; Yang, W.; Lu, Y.; Evans, D.; Lee, J. J.; Vail, S.; Zhao, X.; Nishijima, M.; Kakimoto, S.; Goodenough, J. B. Rhombohedral prussian white as cathode for rechargeable sodium-ion batteries. J. Am. Chem. Soc. 2015, 137, 2548-2554.

(15) Lee, H. W.; Wang, R. Y.; Pasta, M.; Lee, S. W.; Liu, N.; Cui, Y. Manganese hexacyanomanganate open framework as a high-capacity positive electrode material for sodium-ion batteries. Nat. Commun. 2014, 5, 5280.

(16) Park, Y.U.; Seo, D.H.; Kwon, H. S.; Kim, B.; Kim, J.; Kim, H.; Kim, I.; Yoo, H.I; Kang, $\mathrm{K}$. A new high-energy cathode for a Na-ion battery with ultrahigh stability. J. Am. Chem. Soc. 2013, 135, 13870-13878.

(17) Yabuuchi, N.; Kajiyama, M.; Iwatate, J.; Nishikawa, H.; Hitomi, S.; Okuyama, R.; Usui, R.; Yamada, Y.; Komaba, S. P2-type $\mathrm{Na}_{x}\left[\mathrm{Fe}_{1 / 2} \mathrm{Mn}_{1 / 2}\right] \mathrm{O}_{2}$ made from earth-abundant elements for rechargeable Na batteries. Nat. Mater. 2012, 11, 512-517. 